\title{
Gas emissions at the continental margin west of Svalbard: mapping, sampling, and quantification
}

\author{
H. Sahling ${ }^{1}$, M. Römer ${ }^{1}$, T. Pape ${ }^{1}$, B. Bergès ${ }^{2}$, C. dos Santos Fereirra ${ }^{1}$, J. Boelmann ${ }^{3,4}$, P. Geprägs ${ }^{1}$, M. Tomczyk ${ }^{1}$, \\ N. Nowald ${ }^{1}$, W. Dimmler ${ }^{5}$, L. Schroedter ${ }^{1}$, M. Glockzin ${ }^{6}$, and G. Bohrmann ${ }^{1}$ \\ ${ }^{1}$ MARUM and Department of Geoscience, Klagenfurter Str., 28359 Bremen, Germany \\ ${ }^{2}$ Institute of Sound and Vibration Research, University of Southampton, University Road, Southampton SO17 1BJ, UK \\ ${ }^{3}$ Hochschule Bremerhaven, Labor für Maritime Technologien, An der Karlstadt 8, 27568 Bremerhaven, Germany \\ ${ }^{4}$ Institute for Chemistry and Biology of the Marine Environment, University of Oldenburg, Carl-von-Ossietzky-Str. 9-11, \\ 26111 Oldenburg, Germany \\ ${ }^{5}$ FIELAX, Gesellschaft für wissenschaftliche Datenverarbeitung mbH, Schleusenstr. 14, 27568 Bremerhaven, Germany \\ ${ }^{6}$ Institute of Baltic Sea Research, Warnemünde, Chemical Oceanography, Seestr. 15, 18119 Warnemünde, Germany
}

Correspondence to: H. Sahling (hsahling@ marum.de)

Received: 26 March 2014 - Published in Biogeosciences Discuss.: 20 May 2014

Revised: 13 September 2014 - Accepted: 19 September 2014 - Published: 6 November 2014

\begin{abstract}
We mapped, sampled, and quantified gas emissions at the continental margin west of Svalbard during $\mathrm{R} / \mathrm{V}$ Heincke cruise He-387 in late summer 2012. Hydroacoustic mapping revealed that gas emissions were not limited to a zone just above $396 \mathrm{~m}$ water depth. Flares from this depth have gained significant attention in the scientific community in recent years because they may be caused by bottom-water warming-induced hydrate dissolution in the course of global warming and/or by recurring seasonal hydrate formation and decay. We found that gas emissions occurred widespread between about 80 and $415 \mathrm{~m}$ water depth, which indicates that hydrate dissolution might only be one of several triggers for active hydrocarbon seepage in that area. Gas emissions were remarkably intensive at the main ridge of the Forlandet moraine complex in 80 to $90 \mathrm{~m}$ water depths, and may be related to thawing permafrost.

Focused seafloor investigations were performed with the remotely operated vehicle (ROV) "Cherokee". Geochemical analyses of gas bubbles sampled at about $240 \mathrm{~m}$ water depth as well as at the $396 \mathrm{~m}$ gas emission sites revealed that the vent gas is primarily composed of methane (>99.70\%) of microbial origin (average $\delta^{13} \mathrm{C}=-55.7 \%$ V-PDB).

Estimates of the regional gas bubble flux from the seafloor to the water column in the area of possible hydrate decomposition were achieved by combining flare mapping using multibeam and single-beam echosounder data, bubble
\end{abstract}

stream mapping using a ROV-mounted horizontally looking sonar, and quantification of individual bubble streams using ROV imagery and bubble counting. We estimated that about $53 \times 10^{6}$ mol methane were annually emitted at the two areas and allow for a large range of uncertainty due to our method ( 9 to $118 \times 10^{6} \mathrm{~mol} \mathrm{yr}^{-1}$ ). First, these amounts show that gas emissions at the continental margin west of Svalbard were on the same order of magnitude as bubble emissions at other geological settings; second, they may be used to calibrate models predicting hydrate dissolution at present and in the future; and third, they may serve as a baseline (year 2012) estimate of the bubble flux that will potentially increase in the future due to ever-increasing global-warming-induced bottom water warming and hydrate dissociation.

\section{Introduction}

The Arctic is warming faster than any other region on Earth, and, at the same time, gas hydrates in Arctic continental margins store significant amounts of methane (Archer and Buffett, 2005). As hydrates are stable under low-temperature and high-pressure conditions, gas hydrates in high-latitude regions that are characterized by relatively low bottom-water temperatures can persist in relatively shallow water depths. Because those regions are highly sensitive to increases in 
bottom-water temperatures in the course of global warming, shallow hydrates are highly susceptible to thermal dissociation, which might lead to methane release from the seafloor. Moreover, methane escaping the seafloor at shallow depths eventually reaches the atmosphere, where it could contribute to the inventory of greenhouse gases. In this light, findings by Westbrook et al. (2009) were alarming: numerous gas emissions occurred at the continental margin west of Svalbard concentrated along a band at seafloor depths just above the $396 \mathrm{~m}$ isobath, which is the present top of the gas hydrate stability zone (GHSZ). During the last three decades, the bottom water at that depth has experienced a warming trend of $1{ }^{\circ} \mathrm{C}$ (Westbrook et al., 2009). The authors assumed that the warming has induced a deepening of the upper boundary of the GHSZ from a depth of about $360 \mathrm{~m} 30$ years ago to the present limit at $396 \mathrm{~m}$, which could have caused hydrate dissociation in the sediments and, as a consequence, release of gas bubbles. The "396 m flares", as we call the site here, would be the first site where the hypothesis of globalwarming-induced hydrate dissociation may actually be confirmed.

Westbrook et al. (2009) offered an alternative hypothesis for the shelf-parallel occurrences of seafloor gas emissions. Free methane in deep continental slope sediments may migrate upward along the base of the GHSZ landward to the depths where it pinches out, which could also explain the clustering of gas emissions at $396 \mathrm{~m}$ depth. A prerequisite of this second hypothesis would be a capacious gas reservoir in deeper sediments supplying sufficient gas (primarily methane) to the gas emission sites. Indeed, data available so far suggest that the continental margin west of Svalbard is prone to hydrocarbon seepage at the seafloor: the presence of gas hydrates (below $\sim 600 \mathrm{~m}$ water depth) and free gas below the base of the GHSZ is indicated by the presence of a bottom-simulating reflector (Vanneste et al., 2005; Westbrook et al., 2008; Chabert et al., 2011). In addition, hydrates were recovered from shallow sediments in $\sim 900 \mathrm{~m}$ water depth (Fisher et al., 2011). Gas-related seismic facies occur at the upper slope and outer shelf (Sarkar et al., 2012; Rajan et al., 2012). Gas emissions occur not only at the $396 \mathrm{~m}$ flares on the upper slope but also at the outer shelf at water depths up to $150 \mathrm{~m}$ (Westbrook et al., 2009). Typical hydrocarbon seep-related bacterial mats were observed at the shelf (Knies et al., 2004). Elevated bottom-water methane concentrations and the stable carbon isotope composition of methane in the water column indicate seepage at the shelf (Damm et al., 2005; Gentz et al., 2014).

A third hypothesis of a seasonally varying thickness of the GHSZ was recently posed by Berndt et al. (2014). Uraniumthorium dating on massive methane-derived authigenic carbonates sampled at the seafloor at the $396 \mathrm{~m}$ flares ("MASOX site") revealed ages of up to 3000 years. These findings suggest a long history of methane venting, which argues against the hypothesis of recent global-warming-induced hydrate decay. In addition, seasonal fluctuations of $1-2^{\circ} \mathrm{C}$ in the bottom-water temperature measured with a seafloordeployed mooring over a period of almost 2 years might cause periodic hydrate formation and dissociation (Berndt et al., 2014). However, a seasonally growing and declining thickness of the GHSZ should, consequently, result in seasonal fluctuations in gas bubble emissions, with more intensive emissions during the time of a retreating GHSZ from about June to December (warmer bottom water) and less intensive (or no) emissions from January to May (colder bottom water).

The amount of hydrate-bound methane that could potentially be released during dissociation was estimated in several modeling studies at the margin west of Svalbard but is still uncertain since reported numbers span about 3 orders of magnitude. The rates are given as annual amount of moles of methane released from hydrate dissociation per meter of margin segment. The initially reported rate of global-warming-induced release of hydrate-bound methane of $56.1 \times 10^{3} \mathrm{~mol} \mathrm{yr}^{-1} \mathrm{~m}^{-1}$ (Westbrook et al., 2009) was later scaled down to $8.8 \times 10^{3} \mathrm{~mol} \mathrm{yr}^{-1} \mathrm{~m}^{-1}$ (Reagan et al., 2011). For the future, a methane release rate from dissociating hydrates between 6.9 and $20.6 \times 10^{3} \mathrm{~mol} \mathrm{yr}^{-1} \mathrm{~m}^{-1}$ (10 years) and 13.2 and $72.3 \times 10^{3} \mathrm{~mol} \mathrm{yr}^{-1} \mathrm{~m}^{-1}$ (30 years) depending on different climate scenarios considered is expected (Marín-Moreno et al., 2013). Comparably high rates with up to 561 to $935 \times 10^{3} \mathrm{~mol} \mathrm{CH}_{4} \mathrm{yr}^{-1} \mathrm{~m}^{-1} \mathrm{kept}$ or released in/from the seasonal gas hydrate mass were estimated by Berndt et al. (2014).

The main objective of this study is to quantify the amount of methane emitted as gas bubbles from the seafloor to the water column. We assume that most of the methane flux, derived from dissociating hydrate or directly from a free gas reservoir, is released as gas bubbles. Our study provides a useful mean of assessing the significance of the bubble flux, it can be used to calibrate models of hydrate dissolution, and, further, it can serve as a baseline (year 2012) estimate of the methane flux that is likely to increase in the future due to the ongoing warming trend. The quantification is based on the combination of shipborne systematic hydroacoustic flare mapping and remotely operated vehicle (ROV)-based estimation of the bubble flux of individual bubble streams. A further objective of our study is to map the distribution of gas emissions at the shelf and the upper continental slope west of Svalbard. Although we are not able to contribute to the ongoing discussion of whether or not hydrate dissociation is the cause of the bubble emissions, flare distributions determined in the study area put the significance of the $396 \mathrm{~m}$ flares into perspective. Finally, samples of gas bubbles and geochemical analyses give insight into the genesis (thermogenic versus microbial) of emitted gas. 


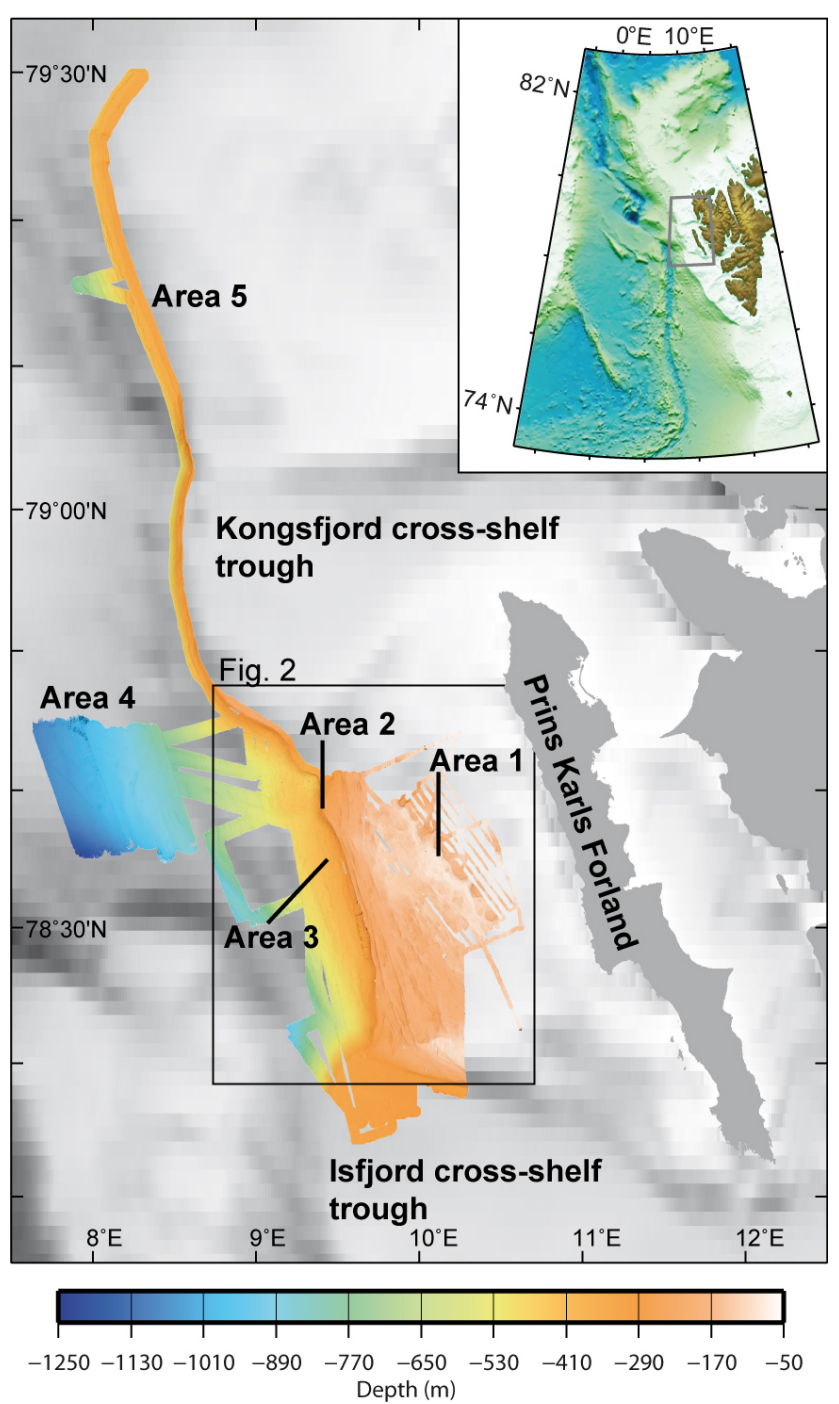

Figure 1. Multibeam bathymetry obtained during R/V Heincke cruise He-387 (color) plotted on IBACO bathymetry (Jakobsson et al., 2008) showing the study areas (Areas 1 to 5) at the continental margin west of Svalbard. Inset shows an overview map with the location of the main map.

\section{Study area}

The study area is located west of Svalbard (Fig. 1). The continental margin was shaped by the advances and retreats of the ice sheet covering Svalbard and the Barents Sea during the Pliocene-Pleistocene (Solheim et al., 1998; Vorren et al., 1998). Fast-flowing ice streams created the cross-shelf troughs seaward of the major fjord systems Kongsfjord and Isfjord. The inter-trough region west of Prins Karls Forland was covered by slow-flowing ice sheets, with the shelf break marking approximately the seaward extent of the maximal ice coverage (Landvik et al., 1998). The shelf was flooded as glacial ice retreated about 13000 years ago (Landvik et al., 2005). Large areas of the shelf were mapped by the Nor- wegian Hydrographic Survey (Landvik et al., 2005) and the University of Troms $\varnothing$ (Ottesen et al., 2007). The existing multibeam data cover the shelf area east and north of the area shown in Fig. 2 with some overlap in the central part. The Forlandet moraine complex is a pronounced ridge system at the middle slope with a crest in about $90 \mathrm{~m}$ water depth (Landvik et al., 2005). During a cruise in 2011 with the R/V James Clarke Ross, gas emissions were found at the Forlandet moraine complex (Wright, 2012), an area that, for simplicity, we call Area 1 in the following. Additional evidence for hydrocarbon seepage at the shelf was presented by Knies et al. (2004), who discovered seep-typical sulfur-oxidizing bacterial mats using an ROV.

The gas emissions discovered by Westbrook et al. (2009) are located at the outer shelf (Area 2 in this study) and upper continental slope (Area 3). The misalignment between gas vents at $\sim 240 \mathrm{~m}$ water depth (Area 2) and at $396 \mathrm{~m}$ (Area 3) (Fig. 2) is caused by the combined action of a slump acting as seal for upward-migrating fluids and glacigenic debris flows, which channel fluids along their base landward, as geophysical studies have revealed (Rajan et al., 2012; Sarkar et al., 2012). Further landward of the prograding glacigenic sequences, pockmarks exist at the seafloor (Fig. 2), and a seismic image shows that one pockmark was underlain by an acoustic pipe structure, but as no gas emissions have been observed so far, they are probably relict structures of fluid emission (Rajan et al., 2012).

Two high-resolution seismic studies were carried out in the area of potential global-warming-induced hydrate dissociation (Area 2 and 3 ) that led to different conclusions. The study by Rajan et al. (2012) focused on the region including Area 2 and the northernmost part of Area 3 (Fig. 2), that is affected by glacigenic debris flows. The authors imaged a gas cloud in the sediment below the landward limit of the GHSZ that they interpret as a possible migration pathway of deep (thermogenic) gas. They conclude that the gas may be temporarily sequestered as gas hydrates, but seismic evidence for this is lacking, and thus any involvement of global-warminginduced hydrate dissociation is speculative. However, based on a seismic data set covering the entire Area 3, Sarkar et al. (2012) argue that evidence for fault-controlled gas migration from deeply buried sediments, which could explain the contour-following trend of the flares originating at $396 \mathrm{~m}$ water depth, is missing. Instead, bright spots at shallow sediment depths close to the landward limit of the GHSZ would be in accordance with global-warming-induced hydrate dissociation.

While glacigenic sedimentation was predominant at the shelf and upper slope, the distal slope was influenced by hemipelagic sedimentation and bottom water currents, leading to the development of contourite drifts (Eiken and Hinz, 1993). Vestnesa Ridge is a contourite with evidence for a very active hydrocarbon venting system (Hustoft et al., 2009). Southeast of Vestnesa Ridge in Area 4, pockmarklike seafloor depressions exist between 800 and $1200 \mathrm{~m}$ water 


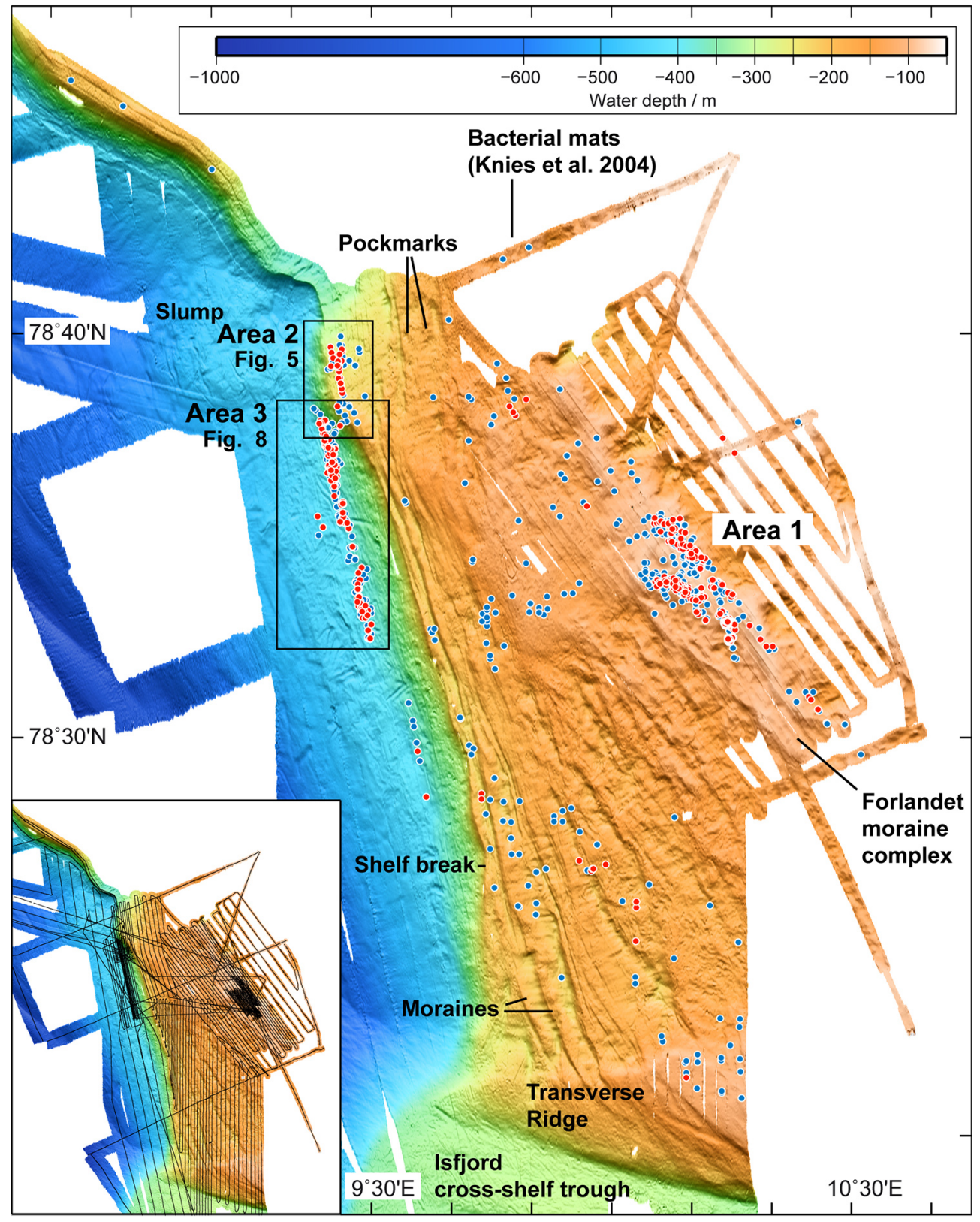

Figure 2. Main figure: location of flares (hydroacoustic indications of gas bubble emissions) during summer 2012 as picked from EK 60 echosounder records plotted on top of multibeam bathymetry. Strong flares (red dots) mainly occur in Areas 1, 2, and 3. Weak flares (blue dots) occur widespread at the shelf. Inset: map of the region showing the ship track and bathymetry.

depth (Fig. 1). The presence of gas hydrates in the sediments was inferred from a well-pronounced bottom-simulating reflector (Sarkar et al., 2012) and proven by gravity coring (Fisher et al., 2011).

\section{Material and methods}

The study is based on R/V Heincke cruise no. 387 (20 Aug to 9 September 2012) conducting research in the area west of Svalbard (Sahling et al., 2012). The multibeam echosounder
Kongsberg Maritime EM 710 was employed for seafloor charting and water-column flare mapping. The system operates at frequencies between 70 and $100 \mathrm{kHz}$. It has 200 beams each with an opening angle of $1^{\circ}$ across track and $2^{\circ}$ along track. The footprint of the echosounder across track is therefore about $1.7 \%$ of the water depth. Two data sets for seafloor mapping (*.all files) and water column mapping (*.wcd files) were recorded (available online: http:// doi.pangaea.de/10.1594/PANGAEA.816220). Seafloor data were processed with MB-System (Caress and Chayes, 2001) 
and water column data with the program package by the company Quality Positioning Services BV (QPS) including FM Midwater and Fledermaus. Four sound velocity profiles were obtained during the cruise using a MIDAS sound velocity probe (Valeport).

The scientific single-beam echosounder EK 60 operates with up to four frequencies, but for the purpose of this study, only the $38 \mathrm{kHz}$ frequency was analyzed for mapping and flare classification purposes. Data were recorded with the ER 60 software, stored as *.raw files (available online: http:// doi.pangaea.de/10.1594/PANGAEA.816056), and processed using the readEKRaw MATLAB toolkit (by Rick Towler, NOAA Alaska Fisheries Science Center; available online: http://hydroacoustics.net/viewtopic.php? $\mathrm{f}=36 \& \mathrm{t}=131$ ). The toolkit was used to convert the data into Sv, which is the volume backscattering per unit volume expressed in $\mathrm{dB}$ re $1 \mathrm{~m}^{-1}$. Sv is often used when individual targets are very small in the sampled volume as several echoes are combined to give a certain signal level. A toolkit for mapping flares was designed. This consists of an interface where the user reads echosounder traces and is asked to manually pick the flares that appear. For each selected flare, an ID (with the format DayMonthNumbering is given and its characteristics are stored (Supplement Fig. S1): the date and time at which it was observed, its longitude and latitude, its strength, the weighted sum of all Sv levels within its trace area, and finally its height. The weighted sum of all Sv levels was made on a linear scale with the purpose of classifying flares into strong and weak. Locations of flares were plotted with GMT using color coding for classifying strong and weak flares (threshold arbitrarily set at $4 \mathrm{~dB}$ re $1 \mathrm{~m}^{-1}$, Fig. 2).

MARUM's ROV Cherokee is a mid-size inspection-class vehicle manufactured by Sub-Atlantic, Aberdeen. Underwater positioning was obtained using the ultra-short baseline system GAPS by Ixsea. Scientific payload of the ROV was a modified, small-sized version of the pressure-tight gas bubble sampler (GBS; Pape et al., 2010), custom-made bubble catchers, and horizontally scanning sonars (Imagenex $881 \mathrm{~A}$ or Tritech) mounted on top of the vehicle to allow for $360^{\circ}$ sonar view. Still images were acquired with a 5megapixel Kongsberg OE-14 camera. Videos were recorded with a Tritech Typhoon PAL camera and stored electronically in AVI format.

The volume flux of bubbles was estimated using a bubble catcher and the video for visual identification. Scaling of the images was obtained by placing objects of known dimensions (such as the ROV manipulator) into the plane where the bubbles occur. Due to the low shutter speed, bubbles appear blurred as long ellipsoids in the video frames, and therefore only one bubble diameter could be measured. From each measure, volumes were calculated assuming spherical bubbles and fluxes were inferred by multiplying the average bubble volume with the emission frequency. The volume flux was then converted to mass flux assuming that the gas consists of pure methane and considering the compressibil- ity of methane (compressibility: 0.91 at $380 \mathrm{~m}$ water depth, 39 bar, $4{ }^{\circ} \mathrm{C}$; compressibility: 0.93 at $240 \mathrm{~m}$ water depth, 25 bar, $4{ }^{\circ} \mathrm{C}$ ). A SBE911plus Sea-Bird Electronic CTD was used to acquire hydrographic parameters. Gas collected with the GBS was analyzed with a two-channel $6890 \mathrm{~N}$ (Agilent Technologies) gas chromatograph described in detail in Pape et al. (2010). Hydrate phase boundaries were calculated using the HWHYD U.K. software (Masoudi and Tohidi, 2005).

\section{Results}

\subsection{Flare mapping}

A total of 1920 nautical miles of hydroacoustic profiles were acquired during the He-387 cruise (Fig. 1). For simplicity, we subdivided the region into five areas. Flares in the water column were found at the continental shelf (Area 1), close to the shelf break (Area 2), and at the upper continental slope (Area 3), but not above the pockmarks (Area 4), and along the $396 \mathrm{~m}$ depth contour further north (Area 5).

Numerous flares occurred at the shelf and upper slope west of Prins Karls Forland (Fig. 2). Gas emissions concentrate in Areas 1, 2, and 3. Emission sites in Areas 2 and 3 correspond to those discovered by Westbrook et al. (2009) at water depth around 240 and $396 \mathrm{~m}$, respectively. We focused on quantifying the amount of gas emitted in these areas (Sect. 4.3 and 4.4). In addition, we found numerous gas emissions on the shelf at water depths of about 80 to $90 \mathrm{~m}$, and particularly from a $\sim 50 \mathrm{~m}$ high ridge (Area 1) that is part of the Forlandet moraine complex (Landvik et al., 2005). Gas bubble emissions occurred in clusters on the ridge, and even more flares were recognized close to the rim of the plateau on top of the ridge.

In addition to gas emissions in the three main areas ( $\mathrm{Ar}-$ eas 1-3), flares were found widespread at the shelf. Those flares occurred more dispersed compared to the aggregations at the Forlandet moraine complex, and their relative intensity was generally weak compared to those recorded in Areas 1, 2 , and 3. Flares preferentially occurred on topographic highs such as shelf break-parallel ridges that we interpret as recessional moraines. It should be noted, however, that the distribution of the flares as shown in Fig. 2 is biased by the survey line spacing. Dense line spacing increases the chance to hit a bubble emission; therefore, the track line of the ship is plotted in Fig. 2 as well. Another topographic feature on the shelf with a considerable number of gas emissions is the transverse ridge at the northern border of the Isfjord cross-shelf trough. More survey lines would be needed to unravel if this feature was also a significant source region for gas emissions.

We found no evidence for gas bubble emission in Area 4 (Fig. 1) connected to pockmarks, which are rounded to elongated depressions at the seafloor at depths between about 800 and $1200 \mathrm{~m}$. Sixteen pockmarks were crossed during our hydroacoustic surveys, but flares have not been detected in 
the EK 60 records. While pockmarks are generally considered as traces of cold fluid seepage, we conclude that gas bubble emission was not active at the time of investigation.

The $\sim 396 \mathrm{~m}$ depth contour is the relevant depth where flares would be expected to occur if one or both of the hypotheses of global-warming-induced hydrate dissolution or a seasonal GHSZ are correct. Therefore, we expanded our survey along this depth for about $80 \mathrm{~km}$ to the north (Area 5). However, during this survey we found no evidence for bubble emissions, in neither the EM 710 nor the EK 60 records, suggesting that the $396 \mathrm{~m}$ flares were restricted to Area 3 west of Prins Karls Forland.

\subsection{ROV-based observations and vent gas composition}

In total, we conducted nine ROV dives in Areas 1, 2, and 3 (Table 1). The seafloor at Area 1 (80 to $90 \mathrm{~m}$ water depth), which is located at the main ridge of the Forlandet moraine complex, was composed of cobble- to boulder-sized rocks (Fig. 3a) that we interpret as glacial till. Fine-grained sediment filled the space between rocks. Bivalve shells, living sea urchins and other hard-ground biota were observed. Bubble emission sites in Area 1 were patchily distributed. Bubbles rose through rocks or fine-grained sediments, with, in the latter case, whitish microbial mats associated.

In Area 2 ( 240 to $245 \mathrm{~m}$ water depth) the proportion of soft sediment was higher compared to Area 1. However, similar to Area 1, cobble- to bolder-sized rocks of glacigenic origin occurred. In addition, rocks resembling methane-related authigenic carbonates were found associated to bubble streams. Bubbles were released from centimeter-sized fractures. In some places carbonate crusts were fractured, exposing cavities below the crust (Fig. 3b). At some sites bubbles accumulated below crusts, leading to a periodic release of bursts of bubbles alternating with times of quiescence. Microbial mats were observed on soft sediments and around bubble emissions on hard ground.

In Area 3 ("396 m flares"), ROV dives were carried out at three locations. In general, the proportion of soft sediments again was higher compared to that at the shallower sites. As found in Area 2, crusts resembling methane-related authigenic carbonates were present. Microbial mats occurred around bubble emission sites on rocks and on soft sediments. Pogonophora tubeworms (Siboglinidae) covered by microbial mats were observed (Fig. 3f). Swarms of demersal fish were encountered.

Analysis of the composition of gas bubbles sampled with the GBS at six bubble streams in all three areas showed that the gas from Areas 2 and 3 is generally dominated by methane (99.70 to $99.99 \%\left(\Sigma\left(\mathrm{C}_{1}-\mathrm{C}_{3}, \mathrm{CO}_{2}\right)\right)$, Table 2$)$. Only the single gas sample from Area $1(90 \mathrm{~m})$ contained a noticeable fraction of $\mathrm{CO}_{2}(\sim 1 \%)$. The $\mathrm{C}_{1} / \mathrm{C}_{2}$ ratio of all samples ranged between 7800 and 15000 .

\subsection{Quantification of gas fluxes in Area $2(240-245 \mathrm{~m})$}

In order to conduct an order-of-magnitude estimate of the flux of gas emitted in Area 2, we followed a simple approach: first, we quantitatively mapped flares using the water column data acquired with EM 710. During ROV dives we found out that bubble streams occurred in clusters. While one bubble stream may be enough to cause a flare in several instances, more than one stream was encountered in most cases. We therefore studied several clusters and estimated the number of bubble streams per cluster. Finally, we estimated the flux of methane emitted per bubble stream. We then estimated the flux of methane for the entire area by conducting minimum and maximum estimations that encompass a wide range of uncertainty.

In order to quantitatively map flares in Area 2, we used the water column data recorded by EM 710 as illustrated in Fig. 4. The EM 710 survey was designed in such a manner that almost complete coverage of the area (gray shading in Fig. 5) was achieved while significant overlap could be avoided. In total, 512 flares originating from the seafloor in about 240 to $245 \mathrm{~m}$ water column were picked from the EM 710 water column data. Most flares concentrated along lineaments trending parallel to the shelf break. The shelf in this area is flat without discernable morphology based on the swath bathymetry.

Flare intensities varied, but, due to noisy EM 710 data, classification of flare intensities (weak vs. strong) could not be achieved; this was left to the EK60 data. Two ROV dives were conducted in Area 2 (Fig. 6) at sites where weak and strong flares occurred close to each other (Table 1). For practical reasons, we termed a site "cluster" when we found one or more gas emissions within a small area. The appearance of cluster C6 in the sonar record is shown in Fig. 7. Within a distance of less than $\sim 3 \mathrm{~m}$, we observed five bubble streams (S1-S5). We assumed that all these bubble streams contributed to a flare imaged with EM 710 because the distance between the streams $(\max 3 \mathrm{~m})$ was smaller than the footprint size of the EM 710 (about $5 \mathrm{~m} ; 1.7 \%$ of water depth). In total, we found six clusters composed of 1 to 15 bubble streams (average $\sim 6$ ) in Area 2 (Table 3).

At 15 individual bubble emission sites (at five different clusters) we either calculated the gas volume flux by interpreting ROV-based videos (visual quantification) or measured it by placing an inverted funnel (bubble catcher) over the streams (Fig. 3c and d). Application of both methods at two emission sites showed that the differences were less than $25 \%$ (Table 3). On average, $15.2 \mathrm{~mL} \mathrm{~min}^{-1}$ of gas (SD: $7.5 \mathrm{~mL} \mathrm{~min}^{-1}, n=15$ ) was emitted from an emission site. Assuming that the bubbles consisted of pure methane, these rates correspond to methane flux rates of $17 \pm 8 \mathrm{mmol} \mathrm{min}^{-1}$.

Based on the flux rates mentioned above, we estimated the flux of methane as gas bubbles from the seafloor for the entire Area 2. Multiplying the number of 512 known flares existing 

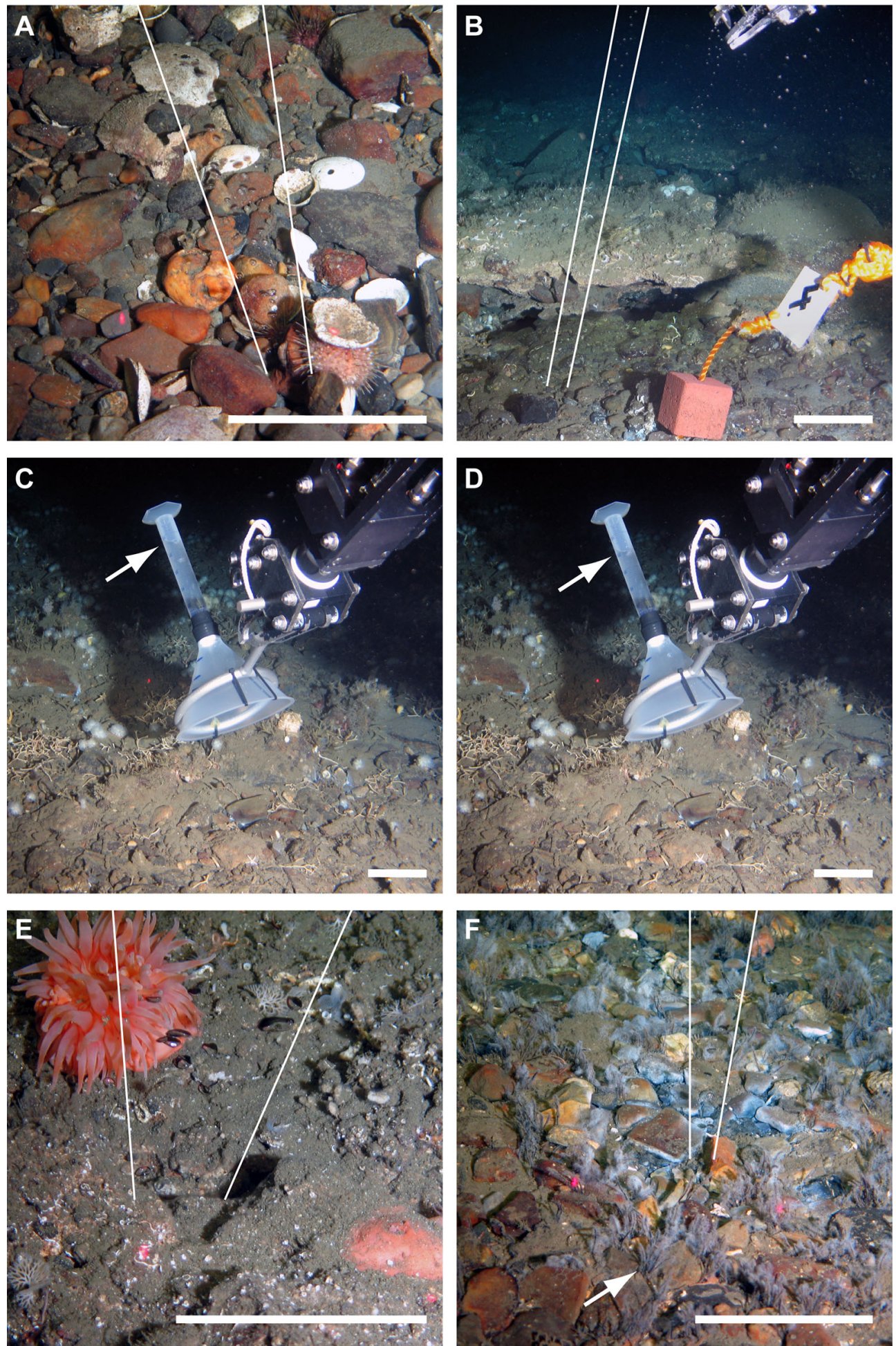

Figure 3. Seafloor images taken during dives with ROV at gas emission sites in Area 1 (a), Area 2 (b-e), and Area 3 (f). Scale bar is $10 \mathrm{~cm}$. Arrows point to objects of interest, and white lines outline the trace of the rising bubbles. (a) Bubbles escaping from the cobble-covered seafloor (Dive 02). (b) Three bubble streams at Marker 4. Crusts resemble authigenic carbonates at the seafloor (Dive 04). (c, d) Images illustrating the use of the bubble catcher for measuring the gas bubble volume flux (Dive 05). (e) Bubbles rising in front of an anemone (Dive 04). (f) Filamentous (probably sulfur-oxidizing) bacteria and pogonophora at a bubble stream (Dive 08). Photos courtesy of MARUM. 
Table 1. Stations and instruments deployed during R/V Heincke cruise He-387. Abbreviations: ROV, MARUM's remotely operated vehicle Cherokee; GBS, gas bubble sampler; Marker, seafloor-deployed stone with a syntactic floating foam bound to it.

\begin{tabular}{|c|c|c|c|c|c|c|}
\hline Date & Stat. no. & Stat. no. GeoB & Instrument & Latitude & Longitude & Water depth $(\mathrm{m})$ \\
\hline 23 August 2012 & 7 & 16807 & ROV Dive 01 & ca. $78^{\circ} 32.9^{\prime} \mathrm{N}$ & ca. $10^{\circ} 14.2^{\prime} \mathrm{E}$ & 91 \\
\hline 23 August 2012 & $7-1$ & $16807-1$ & Marker 2 & $78^{\circ} 32.839^{\prime} \mathrm{N}$ & $10^{\circ} 14.247^{\prime} \mathrm{E}$ & 94 \\
\hline 23 August 2012 & $7-2$ & $16807-2$ & GBS 1 & $78^{\circ} 32.839^{\prime} \mathrm{N}$ & $10^{\circ} 14.252^{\prime} \mathrm{E}$ & 94 \\
\hline 23 August 2012 & $7-3$ & $16807-3$ & GBS 2 & $78^{\circ} 32.840^{\prime} \mathrm{N}$ & $10^{\circ} 14.247^{\prime} \mathrm{E}$ & 94 \\
\hline 24 August 2012 & 12 & 16812 & ROV Dive 02 & ca. $78^{\circ} 32.8^{\prime} \mathrm{N}$ & ca. $10^{\circ} 14.3^{\prime} \mathrm{E}$ & 83 \\
\hline 25 August 2012 & 16 & 16816 & ROV Dive 03 & ca. $78^{\circ} 32.8^{\prime} \mathrm{N}$ & ca. $10^{\circ} 14.2^{\prime} \mathrm{E}$ & 94 \\
\hline 27 August 2012 & 23 & 16823 & ROV Dive 04 & ca. $78^{\circ} 39.2^{\prime} \mathrm{N}$ & ca. $9^{\circ} 25.8^{\prime} \mathrm{E}$ & 241 \\
\hline 27 August 2012 & $23-1$ & $16823-1$ & Marker 1 & $78^{\circ} 39.253^{\prime} \mathrm{N}$ & $9^{\circ} 25.760^{\prime} \mathrm{E}$ & 241 \\
\hline 27 August 2012 & $23-2$ & $16823-2$ & GBS 1 & $78^{\circ} 39.254^{\prime} \mathrm{N}$ & $9^{\circ} 25.755^{\prime} \mathrm{E}$ & 242 \\
\hline 27 August 2012 & $23-4$ & $16823-4$ & Marker 4 & $78^{\circ} 39.252^{\prime} \mathrm{N}$ & $9^{\circ} 26.044^{\prime} \mathrm{E}$ & 241 \\
\hline 27 August 2012 & $23-5$ & $16823-5$ & GBS 2 & $78^{\circ} 39.252^{\prime} \mathrm{N}$ & $9^{\circ} 26.041^{\prime} \mathrm{E}$ & 240 \\
\hline 28 August 2012 & 26 & 16826 & ROV Dive 05 & ca. $78^{\circ} 39.2^{\prime} \mathrm{N}$ & ca. $9^{\circ} 26.0^{\prime} \mathrm{E}$ & 243 \\
\hline 30 August 2012 & 33 & 16833 & ROV Dive 06 & ca. $78^{\circ} 37.1^{\prime} \mathrm{N}$ & ca. $9^{\circ} 24.6^{\prime} \mathrm{E}$ & 382 \\
\hline 30 August 2012 & $33-1$ & $16833-1$ & Marker 5 & $78^{\circ} 37.220^{\prime} \mathrm{N}$ & $9^{\circ} 24.659^{\prime} \mathrm{E}$ & 381 \\
\hline 30 August 2012 & $33-2$ & $16833-2$ & GBS 1 & $78^{\circ} 37.218^{\prime} \mathrm{N}$ & $9^{\circ} 24.659^{\prime} \mathrm{E}$ & 382 \\
\hline 30 August 2012 & $33-3$ & $16833-3$ & GBS 2 & $78^{\circ} 37.210^{\prime} \mathrm{N}$ & $9^{\circ} 24.570^{\prime} \mathrm{E}$ & 384 \\
\hline 30 August 2012 & $33-4$ & $16833-4$ & Marker 3 & $78^{\circ} 37.209^{\prime} \mathrm{N}$ & $9^{\circ} 24.565^{\prime} \mathrm{E}$ & 384 \\
\hline 2 September 2012 & 46 & 16846 & ROV Dive 07 & ca. $78^{\circ} 35.4^{\prime} \mathrm{N}$ & ca. $9^{\circ} 26.5^{\prime} \mathrm{E}$ & 386 \\
\hline 3 September 2012 & 48 & 16848 & ROV Dive 08 & ca. $78^{\circ} 33.4^{\prime} \mathrm{N}$ & ca. $9^{\circ} 28.3^{\prime} \mathrm{E}$ & 391 \\
\hline 3 September 2012 & $48-1$ & $16848-1$ & Marker 8 & $78^{\circ} 33.334^{\prime} \mathrm{N}$ & $9^{\circ} 28.509^{\prime} \mathrm{E}$ & 387 \\
\hline 3 September 2012 & $48-2$ & $16848-2$ & GBS & $78^{\circ} 33.326^{\prime} \mathrm{N}$ & $9^{\circ} 28.558^{\prime} \mathrm{E}$ & 387 \\
\hline 4 September 2012 & 53 & 16853 & ROV Dive 09 & ca. $78^{\circ} 34.5^{\prime} \mathrm{N}$ & ca. $10^{\circ} 10.2^{\prime} \mathrm{E}$ & 90 \\
\hline
\end{tabular}

Table 2. Proportions of low-molecular-weight alkanes and $\mathrm{CO}_{2}$ (in mol.\% of $\Sigma\left(\mathrm{C}_{1}-\mathrm{C}_{3}, \mathrm{CO}_{2}\right)$ ) in vent gas samples taken with the gas bubble sampler (b.d.l.: below detection limit).

\begin{tabular}{cccccccccc}
\hline Area & Depth & $\begin{array}{c}\text { ROV } \\
\text { dive }\end{array}$ & GeoB & $\begin{array}{c}\mathrm{CH}_{4} \\
(\mathrm{~mol}-\%)\end{array}$ & $\begin{array}{c}\mathrm{C}_{2} \mathrm{H}_{6} \\
(\mathrm{~mol}-\%)\end{array}$ & $\begin{array}{c}\mathrm{CO}_{2} \\
(\mathrm{~mol}-\%)\end{array}$ & $\begin{array}{c}\mathrm{C}_{3} \mathrm{H}_{8} \\
(\mathrm{~mol}-\%)\end{array}$ & $\mathrm{C}_{1} / \mathrm{C}_{2}$ & $\begin{array}{c}\delta^{13} \mathrm{C}_{-} \mathrm{CH}_{4} \\
(\% \text { - V-PDB })\end{array}$ \\
\hline Area 1 & $90 \mathrm{~m}$ & 01 & $16807-2$ & 98.977 & 0.013 & 1.009 & $<0.001$ & 7852 & -43.5 \\
Area 2 & $240 \mathrm{~m}$ & 04 & $16823-1$ & 99.689 & 0.007 & 0.303 & $<0.001$ & 15161 & -55.8 \\
Area 2 & $240 \mathrm{~m}$ & 04 & $16823-3$ & 99.730 & 0.007 & 0.261 & $<0.001$ & 13919 & -55.7 \\
Area 3 & $380 \mathrm{~m}$ & 06 & $16833-2$ & 99.991 & 0.008 & b.d.1. & $<0.001$ & 12213 & -53.8 \\
Area 3 & $380 \mathrm{~m}$ & 06 & $16833-3$ & 99.858 & 0.010 & 0.131 & $<0.001$ & 10325 & -57.4 \\
Area 3 & $380 \mathrm{~m}$ & 08 & $16848-2$ & 99.703 & 0.010 & 0.286 & $<0.001$ & 9697 & -56.0 \\
\hline
\end{tabular}

in Area 2 by average numbers of 6 individual bubble streams per cluster (Table 3 ), as well as average methane flux rates at each bubble stream $\left(17 \mathrm{mmol} \mathrm{min}^{-1}\right)$, and assuming that the gas is pure methane, $52 \mathrm{molCH}_{4} \mathrm{~min}^{-1}$ is emitted in Area 2.

We further estimated minimum and maximum flux rates by considering the uncertainties inherent to the approach. An uncertainty of more than 1 order of magnitude is introduced by the number of bubble streams feeding a flare as it varied between 1 and 15 (Table 3). The variability of the flux of a bubble stream $\left(17 \pm 8 \mathrm{mmol} \mathrm{min}{ }^{-1}\right)$ is comparably small (less than a factor of 2). Furthermore, we regard other potential sources of errors not detailed here as comparably negligible. Calculated minimum and maximum fluxes, which solely considered that between 1 and 15 bubble streams were found to feed a flare, resulted in flux rates ranging between
9 and $130 \mathrm{~mol} \mathrm{~min}^{-1}$, respectively. Assuming a constant flux over time, the above-mentioned values translate to $27 \times 10^{6}$ (min: $5 \times 10^{6}$; max: $68 \times 10^{6}$ ) $\mathrm{mol} \mathrm{CH}_{4} \mathrm{yr}^{-1}$.

\subsection{Quantification of gas fluxes in Area 3 (“396 m flares”)}

We quantitatively looked for gas emissions with the EM 710 in Area 3 at the upper continental slope (Fig. 8). The distribution of flares was similar to early observations of Westbrook et al. (2009) and confirmed that the majority of flares are located at an interval between 360 and $415 \mathrm{~m}$ water depth.

Preliminary results during our cruise revealed that flares were difficult to pick in the EM 710 data as they were not stable over time and due to the fact that the location of flares at the seafloor varied. Therefore, we used a statistical approach 
Table 3. Gas quantities transported by individual gas bubble streams in Area 2 (240-245 m waterdepth) determined by use of the bubble catcher or by interpretation of video footage.

\begin{tabular}{|c|c|c|c|c|c|c|c|}
\hline Cluster & $\begin{array}{l}\text { No(s). of } \\
\text { bubble } \\
\text { streams }\end{array}$ & $\begin{array}{l}\text { ROV } \\
\text { dive }\end{array}$ & Location & Tools & Stream & $\begin{array}{c}\text { Flux } \mathrm{mL} \mathrm{min}^{-1} \\
\text { visual } \\
\text { quantification }\end{array}$ & $\begin{array}{c}\text { Flux } \mathrm{mL} \mathrm{min}^{-1} \\
\text { bubble } \\
\text { catcher }\end{array}$ \\
\hline \multirow[t]{3}{*}{$\mathrm{C} 1$} & 15 & 04 & & $\begin{array}{l}\text { Marker 1, } \\
\text { GBS }\end{array}$ & S1 & 17.0 & \\
\hline & & & $9^{\circ} 25.760^{\prime} \mathrm{E}$ & & S2 & 9.9 & \\
\hline & & & $241 \mathrm{~m}$ & & S4 & 23.0 & \\
\hline \multirow[t]{5}{*}{$\mathrm{C} 2$} & 12 & 04 & $78^{\circ} 39.252^{\prime} \mathrm{N}$ & $\begin{array}{l}\text { Marker 4, } \\
\text { GBS }\end{array}$ & S1 & 21.7 & \\
\hline & & & $9^{\circ} 26.044^{\prime} \mathrm{E}$ & & S2 & 13.0 & \\
\hline & & & $241 \mathrm{~m}$ & & S4 & 8.5 & \\
\hline & & & & & S5 & 6.6 & \\
\hline & & & & & S6 & 20.5 & \\
\hline $\mathrm{C} 3$ & 1 & 05 & $\begin{array}{l}78^{\circ} 39.216^{\prime} \mathrm{N}, \\
9^{\circ} 25.834^{\prime} \mathrm{E} \\
242 \mathrm{~m}\end{array}$ & & S1 & 26.5 & 27.9 \\
\hline $\mathrm{C} 4$ & 1 & 05 & $\begin{array}{l}78^{\circ} 39.216^{\prime} \mathrm{N}, \\
9^{\circ} 25.786^{\prime} \mathrm{E} ; \\
241 \mathrm{~m}\end{array}$ & & S1 & 5.2 & 4.0 \\
\hline $\mathrm{C} 5$ & 1 & 05 & $\begin{array}{l}78^{\circ} 39.228^{\prime} \mathrm{N}, \\
9^{\circ} 25.735^{\prime} \mathrm{E} \\
242 \mathrm{~m}\end{array}$ & & & & \\
\hline \multirow[t]{5}{*}{ C6 } & 5 & 05 & $78^{\circ} 39.201^{\prime} \mathrm{N}$ & & S1 & & 25.0 \\
\hline & & & $9^{\circ} 25.995^{\prime} \mathrm{E}$ & & S2 & & 19.4 \\
\hline & & & $241 \mathrm{~m}$ & & S3 & & 6.2 \\
\hline & & & & & S4 & & 8.2 \\
\hline & & & & & S5 & & 17.1 \\
\hline
\end{tabular}

Table 4. Estimated number of flares in Area 3 following the approach described in the text and illustrated in Fig. 9.

\begin{tabular}{lllll}
\hline Profile & $\begin{array}{l}\text { Observed } \\
\text { area }\end{array}$ & $\begin{array}{l}\text { Number of flares } \\
\text { in observed area }\end{array}$ & $\begin{array}{l}\text { Ratio observed } \\
\text { area to "seep } \\
\text { area" }\left(3.72 \mathrm{~km}^{2}\right) \\
\text { in \% }\end{array}$ & $\begin{array}{l}\text { Estimated total } \\
\text { number of flares } \\
\text { in "seep area" }\end{array}$ \\
\hline Fig. 9a & $2.35 \mathrm{~km}^{2}$ & 294 & 63.1 & 466 \\
Fig. 9b & $2.89 \mathrm{~km}^{2}$ & 407 & 77.7 & 524 \\
Fig. 9c & $2.88 \mathrm{~km}^{2}$ & 334 & 77.4 & 432 \\
Fig. 9d & $2.38 \mathrm{~km}^{2}$ & 246 & 64.0 & 384 \\
\hline Average & & & & 451.5 \\
\hline
\end{tabular}

as we were mainly interested in how many flares occurred in Area 3 at any given time. For this approach we used four equally spaced hydroacoustic profiles running across the area where most flares group together. By plotting all flare positions picked from the EM 710 record (Fig. 8), we identified that more than $90 \%$ of the flares detected in Area 3 occurred in a restricted NW-SE-trending "seep area" (Fig. 8). We used the data obtained during the four transects crossing this "seep area" to determine the number of flares during each crossing (Fig. 9). Because each crossing covered only part of the "seep area", we calculated the total number of flares by assuming that the flares were regularly distributed. Subsequently, we counted the number of flares within the observed area, which is the seep area within the footprint of the EM 710 (e.g., the red rectangle in Fig. 9a), and extrapolate that number to the entire seep area (Table 4). The resulting average number of 


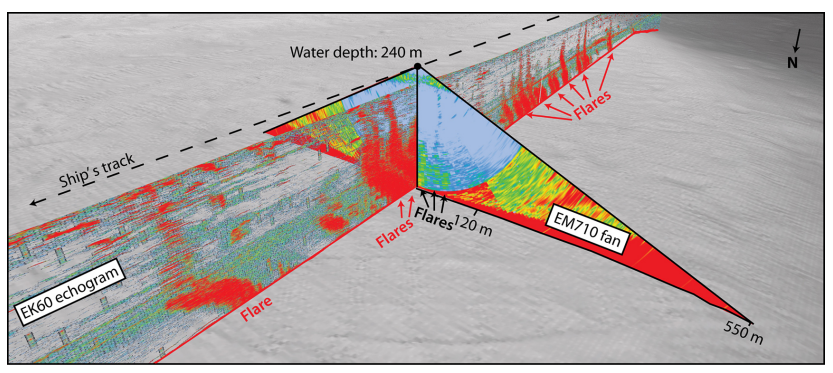

Figure 4. Composite figure illustrating the appearance of flares in the single-beam EK 60 echosounder and in the multibeam EM 710 echosounder. Flares can be traced in the central part of the EM 710 fan $\left(45^{\circ}\right.$ to each side); in this example obtained in $240 \mathrm{~m}$ water depth, the across track width is $120 \mathrm{~m}$ to each side. Beyond that limit, the noise is too high to reliably map flares.

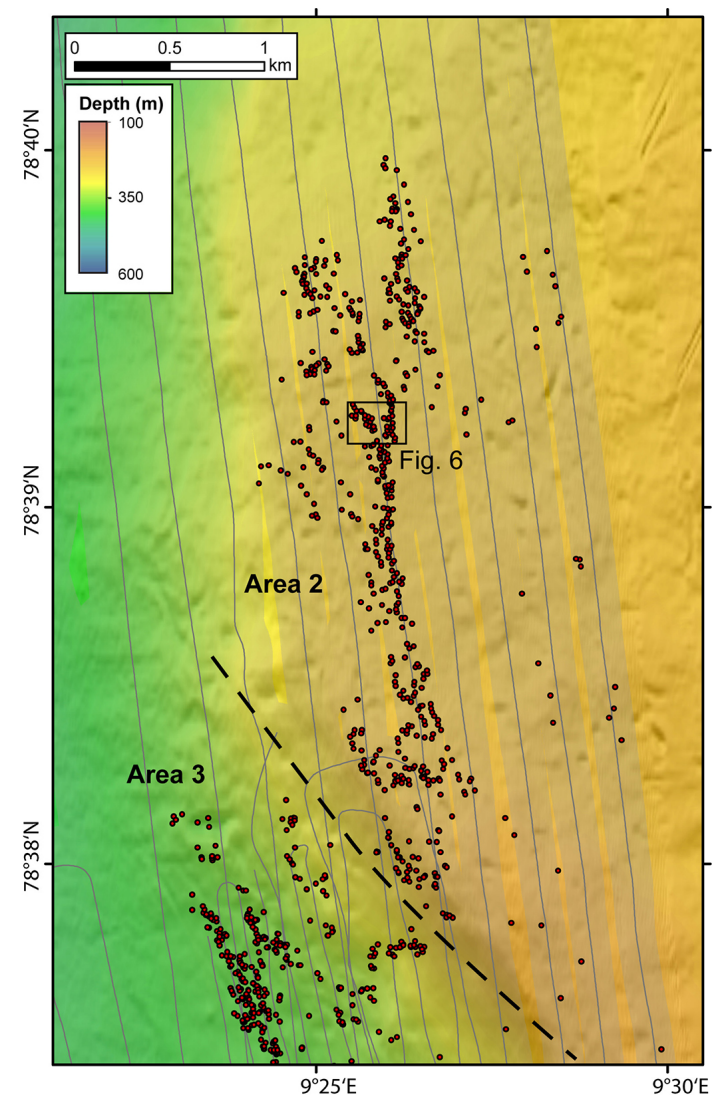

Figure 5. Flares (circles) in Area 2 (240 to $245 \mathrm{~m}$ water depth) plotted on shaded bathymetry. Flares were picked in multibeam water column data; the coverage is shown as gray shading around the ship track (lines). ROV dives were performed in an area highlighted by the rectangular box (Fig. 6).

flares within the "seep area" was 452 . The observed range (min: 384, Fig. 9d; max: 524, Fig. 9b) gave an indication of the uncertainty inherent to the methodology used and the variability of gas emissions.

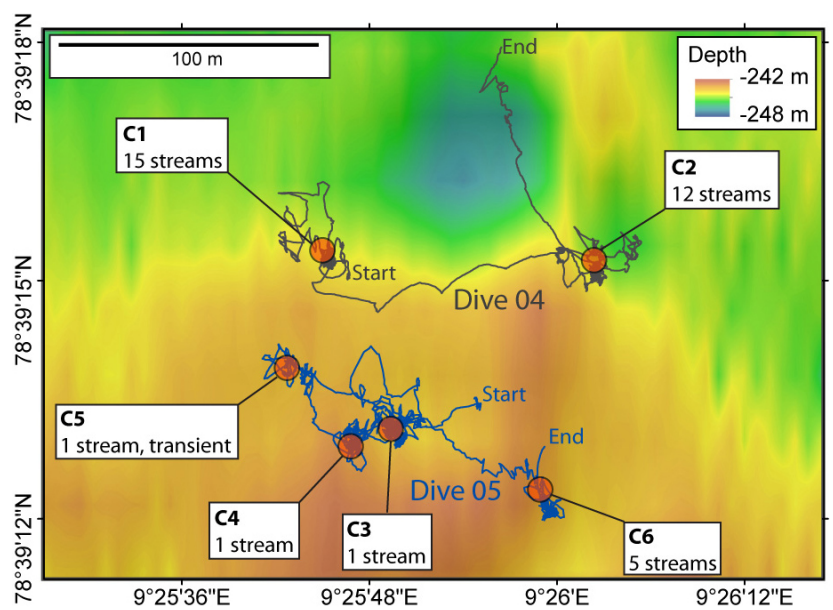

Figure 6. Bubble stream clusters ( $\mathrm{C} 1$ to $\mathrm{C} 6)$ in Area 2 discovered during ROV Dive 04 and 05. Dive tracks are shown on bathymetry.

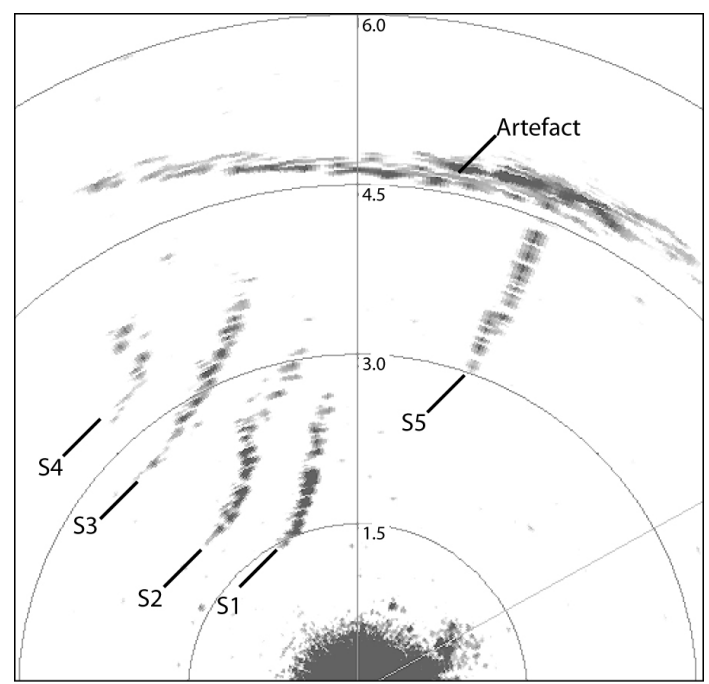

Figure 7. Screenshot of the record from the horizontally looking sonar (Sonar Tritech, $625 \mathrm{kHz}, 6 \mathrm{~m}$ range) mounted on the ROV (Dive 05, 14:37:27 UTC). The image shows the five bubble streams S1 to S5 at cluster C5 at the western edge of the dive track.

The temporal variability of bubble emissions was confirmed during ROV dives. We found that individual bubble streams were transient, with bubbles being emitted for seconds or tens of seconds followed by minutes of inactivity. In addition, the sites of emission changed spatially within a few decimeters. We estimated the number of bubble streams occurring in clusters by observing the area using the horizontally looking sonar for several minutes per site and counted the number of streams that became visible during the observation time. The numbers given in Table 5 reflect maximum values: at a given moment bubbles were emitted only from some sites, i.e., only a fraction of the total number of emission sites was active. The quantified volume flux at several bubble streams resulted in $20.9 \mathrm{~mL} \mathrm{~min}^{-1}$ on average (Table 
Table 5. Gas quantities transported by individual gas bubble streams in Area 3 ("396 m flares") determined by use of the bubble catcher and by interpretation of video footage.

\begin{tabular}{|c|c|c|c|c|c|c|c|}
\hline Cluster & $\begin{array}{l}\text { Number of } \\
\text { bubble } \\
\text { streams }\end{array}$ & Dive & Location & Tools & Stream & $\begin{array}{c}\text { Flux } \mathrm{mL}^{\text {vinin }}{ }^{-1} \\
\text { visual } \\
\text { quantification }\end{array}$ & $\begin{array}{c}\text { Flux mL } \min ^{-1} \\
\text { bubble } \\
\text { catcher }\end{array}$ \\
\hline \multirow[t]{2}{*}{$\mathrm{C} 1$} & 10 & 06 & & $\begin{array}{l}\text { Marker 5, } \\
\text { GBS } 1\end{array}$ & S1 & 9.4 & \\
\hline & & & $\begin{array}{l}9^{\circ} 24.659^{\prime} \mathrm{E} \\
385 \mathrm{~m}\end{array}$ & & & & \\
\hline \multirow[t]{2}{*}{ C3 } & 3 & 06 & & $\begin{array}{l}\text { Marker 3, } \\
\text { GBS } 2\end{array}$ & S1 & 6.7 & \\
\hline & & & $\begin{array}{l}9^{\circ} 24.565^{\prime} \mathrm{E} \\
385 \mathrm{~m}\end{array}$ & & & & \\
\hline \multirow[t]{4}{*}{$\mathrm{C} 5$} & 8 & 07 & $\begin{array}{l}78^{\circ} 35.380^{\prime} \mathrm{N}, \\
9^{\circ} 26.627^{\prime} \mathrm{E} ; \\
385 \mathrm{~m}\end{array}$ & & S1 & & 6.3 \\
\hline & & & & & S2 & & 31.0 \\
\hline & & & & & S3 & & 37.5 \\
\hline & & & & & S4 & & 41.0 \\
\hline \multirow[t]{3}{*}{ C6 } & 8 & 07 & $78^{\circ} 35.381^{\prime} \mathrm{N}$, & & S1 & & 3.0 \\
\hline & & & $385 \mathrm{~m}$ & & & & \\
\hline & & & & & S2 & & 32.0 \\
\hline $\mathrm{C} 7$ & 4 & 07 & $\begin{array}{l}78^{\circ} 35.380^{\prime} \mathrm{N}, \\
9^{\circ} 26.831^{\prime} \mathrm{E} \\
386 \mathrm{~m}\end{array}$ & & & & \\
\hline $\mathrm{C} 8$ & 5 & 07 & $\begin{array}{l}78^{\circ} 33.335^{\prime} \mathrm{N}, \\
9^{\circ} 28.527^{\prime} \mathrm{E} \\
385 \mathrm{~m}\end{array}$ & Marker 8 & & & \\
\hline C9 & 6 & 07 & $\begin{array}{l}78^{\circ} 33.326^{\prime} \mathrm{N} \\
9^{\circ} 28.548^{\prime} \mathrm{E} \\
385 \mathrm{~m}\end{array}$ & & & & \\
\hline C10 & 3 & 07 & $\begin{array}{l}78^{\circ} 33.310^{\prime} \mathrm{N}, \\
9^{\circ} 28.647^{\prime} \mathrm{E} \\
385 \mathrm{~m}\end{array}$ & & & & \\
\hline $\mathrm{C} 11$ & 6 & 07 & $\begin{array}{l}78^{\circ} 33.299^{\prime} \mathrm{N}, \\
9^{\circ} 28.603^{\prime} \mathrm{E} \\
389 \mathrm{~m}\end{array}$ & & & & \\
\hline
\end{tabular}

5). The high variability is reflected in a large standard deviation of $15.9 \mathrm{~mL} \mathrm{~min}^{-1}(n=8)$. The values correspond to a mass flux of $18.3 \pm 9.1 \mathrm{mmol} \mathrm{min}^{-1}$ assuming pure methane.

The total seafloor flux of methane in Area 3 was calculated based on the following numbers: considering average numbers of flares $(n=452)$ and bubble streams per cluster $(n=6)$ and an average $\mathrm{CH}_{4}$ mass flux $\left(18.3 \mathrm{mmol} \mathrm{min}^{-1}\right)$, about 50 moles of methane per minute are emitted in Area 3. Because the uncertainty inherent to this approach is expectedly large, we conducted estimations of the minimum and maximum flux. If we consider that only 384 flares occur in Area 3 (Table 4) and assume that each flare may be sourced by a single bubble stream with an average $\mathrm{CH}_{4}$ mass flux only, this results in a seafloor methane flux of $7 \mathrm{~mol}$ $\mathrm{min}^{-1}$ in Area 3. Calculation of the maximal flux considering the maximum numbers of flares $(n=523)$ and bubble streams found in a cluster $(n=10)$, as well as average mass fluxes, resulted in $96 \mathrm{molCH}_{4} \mathrm{~min}^{-1}$ in Area 3 . These values correspond to fluxes of $26 \times 10^{6}\left(\min 4 \times 10^{6}\right.$, $\left.\max 50 \times 10^{6}\right) \mathrm{mol} \mathrm{CH}_{4} \mathrm{yr}^{-1}$. 


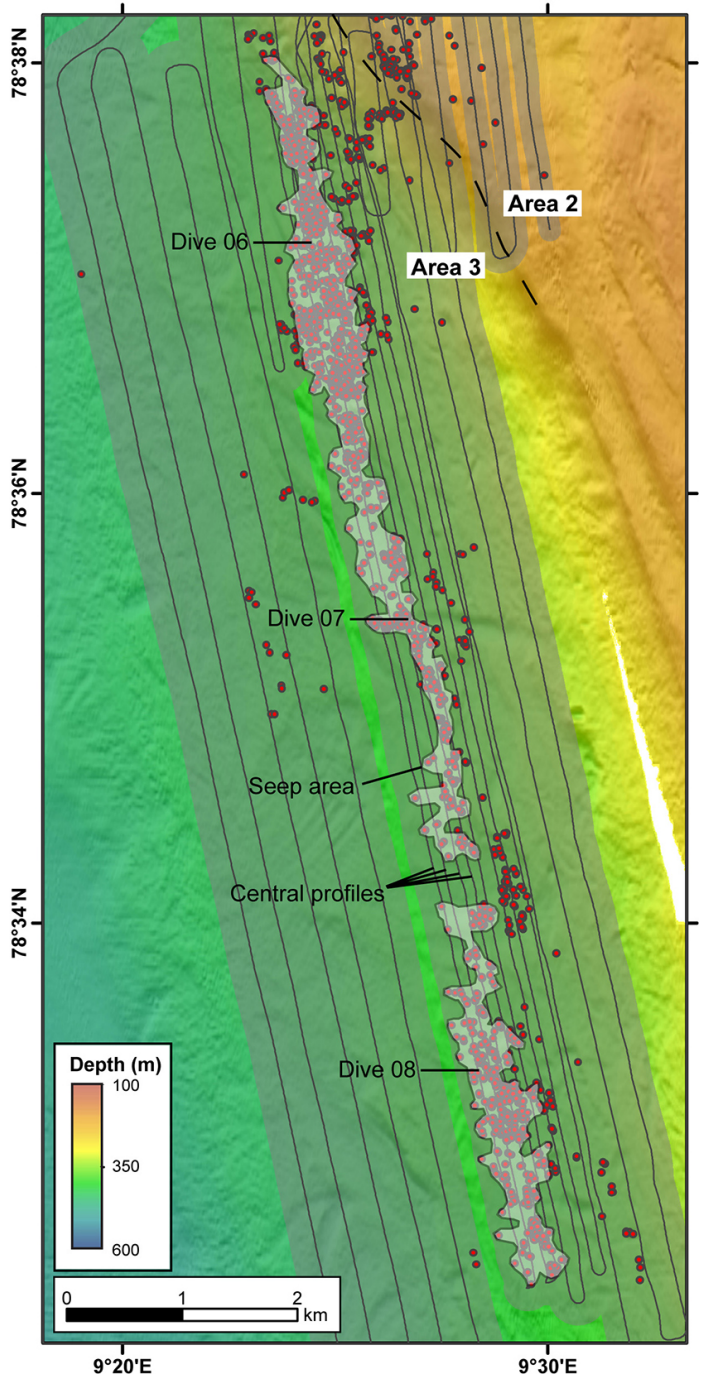

Figure 8. Position of flares (circles) found in Area 3 (" $396 \mathrm{~m}$ flares") plotted on shaded bathymetry. Flares were picked in multibeam water column data; the coverage is shown as dark-gray shading around the ship track (lines). In this study we defined a "seep area" (light-gray shading) in which the number of flares was quantified using the four central profiles (see Fig. 9). The approximate locations of three ROV dives (06-08) are indicated.

\section{Discussion}

\subsection{Sources of methane}

Traditionally, light hydrocarbons of microbial and thermogenic origin are distinguished by the relation of their molecular composition and the methane stable carbon isotope ratio (e.g., Whiticar, 1990). The molecular composition of gas in bubbles collected with the GBS several centimeters above the seafloor in Areas 2 (240 to $245 \mathrm{~m}$ water depth) and Area 3 ("396 m flares") indicate a predominantly microbial origin of the vent gas $\left(\mathrm{C}_{1} / \mathrm{C}_{2}\right.$

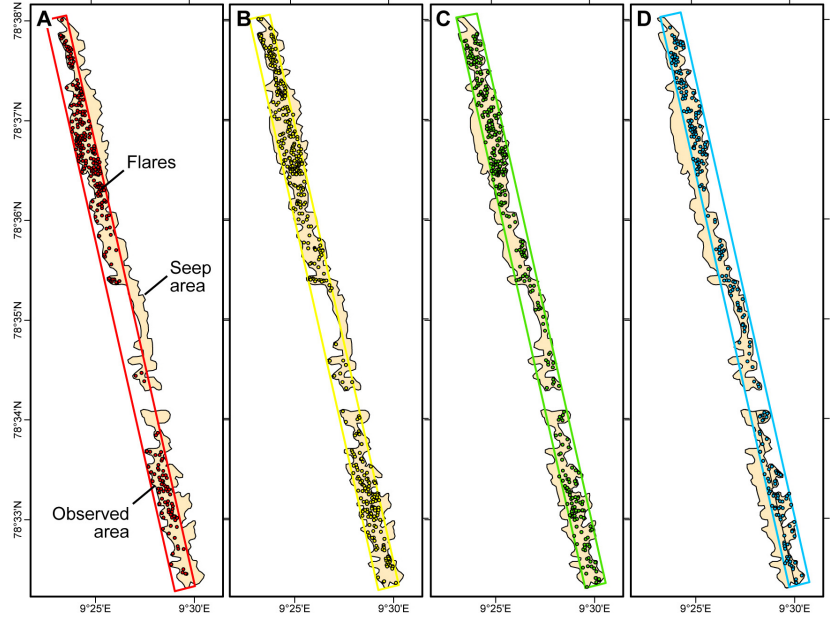

Figure 9. Diagram illustrating the approach of quantifying flares in Area 3. Numbers of flares were estimated within the "observed area", which is the region covered by multibeam (rectangular box) intersecting with the "seep area". Occurrences of flares were repeatedly determined along four parallel profiles (a-d) as indicated in Fig. 8 and summarized in Table 4.

ca. 9700 to 15 200; Fig. 10). However, less negative $\delta^{13} \mathrm{C}$ $\mathrm{CH}_{4}$ ratios (-53.8 to $-57.4 \%$ o V-PDB) than expected from the molecular composition for typical microbial methane point to some admixture of methane enriched in ${ }^{13} \mathrm{C}$. A possible explanation for this observation might be that part of the methane has undergone oxidation within the sediments, which would result in ${ }^{13} \mathrm{C}$ enrichment of the residual methane.

Our finding of gas with an average $\delta^{13} \mathrm{C}$ ratio of $-55.7 \%$ o in Areas 2 and 3 complements well results from water column studies in Area 2 carried out by Gentz et al. (2014). Using correlations between concentration and stable carbon isotopic compositions of methane in the water column, the authors inferred the $\mathrm{C}$-isotope signature of methane emitted from the seafloor (about $-60 \%$ ). A similar $\delta^{13} \mathrm{C}$ ratio $(-54.6 \pm 1.7 \%$ o was reported by Fisher et al. (2011) for methane in hydrates recovered from an area termed "Plume field" ( $890 \mathrm{~m}$ water depth), which is identical to our Area 4. In summary, the source of methane at the upper continental slope and outer shelf (Areas 2, 3, and 4) appears to be similar based on its geochemical signature and largely microbial in origin.

Gas emitted as bubbles at the shelf in Area $1(\sim 90 \mathrm{~m}$ water depth) differs from that sampled in Areas 2 and 3 in its molecular composition $\left(\mathrm{C}_{1} / \mathrm{C}_{2}\right.$ ca. 7850$)$ and $\delta^{13} \mathrm{C}_{-} \mathrm{CH}_{4}$ ratio (-43.5\%o V-PDB) (Fig. 10). This difference is significant, but only a single gas sample could be obtained from Area 1 during our research cruise. Nevertheless, this finding generally agrees with the water column study by Damm et al. (2005) carried out on a much larger scale along the entire SW continental margin of Svalbard. The authors postulated 


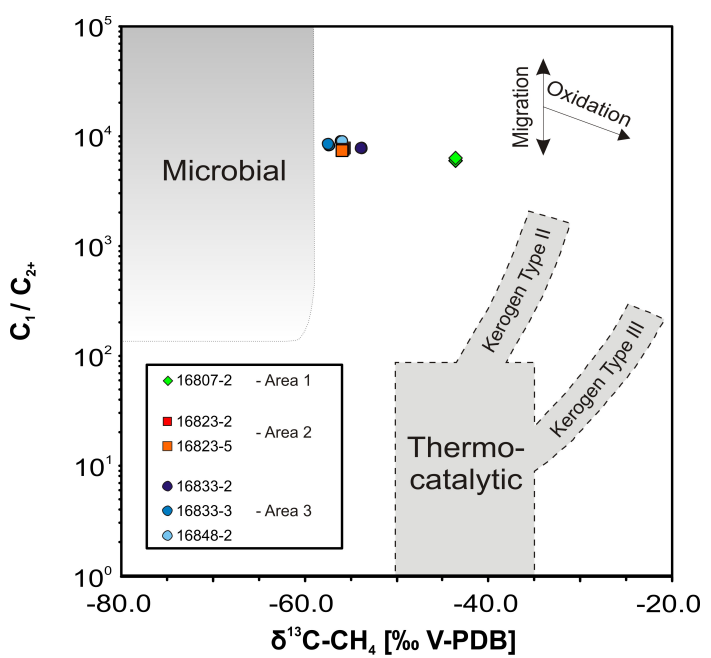

Figure 10. Molecular $\left(\mathrm{C}_{1} / \mathrm{C}_{2+}\right)$ vs. stable $\mathrm{C}$ isotopic composition of methane $\left(\delta^{13} \mathrm{C}-\mathrm{CH}_{4}\right)$ sampled in Areas 1-3. Classification according to the "Bernard diagram" modified after Whiticar (1990). Gas samples studied herein are plotted close to the empirical field of microbial methane except for those from Area 1.

widespread methane seepage along the shelf with respect to methane enrichments at several stations. In addition, the authors observed a topography-dependent methane isotope signature with $-30 \%$ at the tops and $-49 \%$ in troughs. Damm et al. (2005) concluded that the geochemical signature of methane is influenced due to its slow seepage through the sediments leading to "inter-granular seepages" or "microseepages". Our results clearly show that methane emission at the shelf is not limited to micro-seepage, but also occurs as vigorous bubble emission as observed at the main ridge of the Forlandet moraine complex.

Unfortunately, our sparse results on the gas composition and methane isotope signature at the Forlandet moraine complex do not allow for any final assessment of the source of methane (Fig. 10) because migration, oxidation, and in situ generation of gas might have overprinted the original signature. Additional gas samples (e.g., from the deeper subsurface) are needed to ultimately clarify this aspect.

\subsection{Distribution of gas emissions at the seafloor}

The results of our extensive hydroacoustic survey (single beam and swath mapping) provide valuable insight into the system of gas emission at the continental margin west of Svalbard. We have covered large areas while searching for flares with hydroacoustic techniques (Fig. 1), but evidence for gas emissions was restricted to the region west of Prins Karls Forland. This region is apparently prone to fluid flow, as suggested by gas emissions occurring all over the shelf and upper slope. Gas emissions exclusively occur in this inter-fan region bordered by the Kongsfjord cross-shelf trough to the north and the Isfjord cross-shelf trough to the south.
The swath bathymetry acquired during our cruise significantly extends published maps (Landvik et al., 2005; Ottesen et al., 2007) and shows a series of along-shelf, parallel ridges between the shelf break and the Forlandet moraine complex (Fig. 2). We interpret these ridges as surface expressions of prograding foresets, which are sediments deposited at the seaward termination of ice sheets during phases of progression and regression. Because seismic data acquired in the region comprising Areas 2 and 3 show prograding glacigenic sequences at the outer shelf (Rajan et al., 2012; Sarkar et al., 2012), it can be expected that these also occur further to the south. Gas emissions occur all over the shelf with a peculiar clustering at the Forlandet moraine complex. In contrast, the distribution of gas emissions at the shelf distant to the Forlandet moraine complex does not follow any discernable pattern; however, there might be a weak tendency that flares preferentially occur at topographic highs but not in depressions.

Numerous flares were concentrated at the Forlandet moraine complex at water depth of about 80 to $90 \mathrm{~m}$ (Fig. 2). The detailed hydroacoustic surveys conducted during our cruise revealed that almost all flares originated from the top of the moraine, which suggests that the methane source might be located within the morphological ridge itself. However, as we lack data on the sub-seafloor structure, this remains speculative. Potential capacious methane reservoirs at Arctic continental shelves are methane-loaded sediments below permafrost (e.g., Rachold et al., 2007). Transgression of the ocean following the last glacial stage has led to submergence and subsequent dissolution of permafrost in the sediments induced by bottom-water temperatures $>0{ }^{\circ} \mathrm{C}$. If the permafrost seal is broken, methane can escape the reservoir and may be emitted as bubbles from the seafloor, a process recently observed on large scales at the East Siberian Shelf (Shakova et al., 2010). Still-ongoing permafrost melting may thus be an explanation for the concentrated gas emissions observed at the Forlandet moraine complex. If this holds true, a microbial origin of the expelled gas would be expected. Unfortunately, the geochemical properties of the gas sample collected in Area 1 do not allow for unambiguous source assignments. Additional sub-surface gas samples are needed to unravel the gas source at the Forlandet moraine complex.

Flares in Areas 2 and 3 are potentially sourced by dissociating gas hydrates (Westbrook et al., 2009; Berndt et al., 2014). Bubbles in Area 2 are emitted at a shallow depth of about 240 to $245 \mathrm{~m}$ (above the GHSZ). Seismic studies, however, have shown that the flares may also be sourced by dissociating hydrates (Rajan et al., 2012; Sarkar et al., 2012). A slump at the upper slope and prograding foresets led to the landward deviation of upward migrating fluids, such that the gas is emitted along lineaments at the outer shelf (Fig. 5).

Flares in Area 3 are linearly orientated along a band at the upper continental slope at water depth above $\sim 396 \mathrm{~m}$ (Fig. 8). Using the swath echosounder, we systematically mapped the upper slope in order to quantitatively record the 


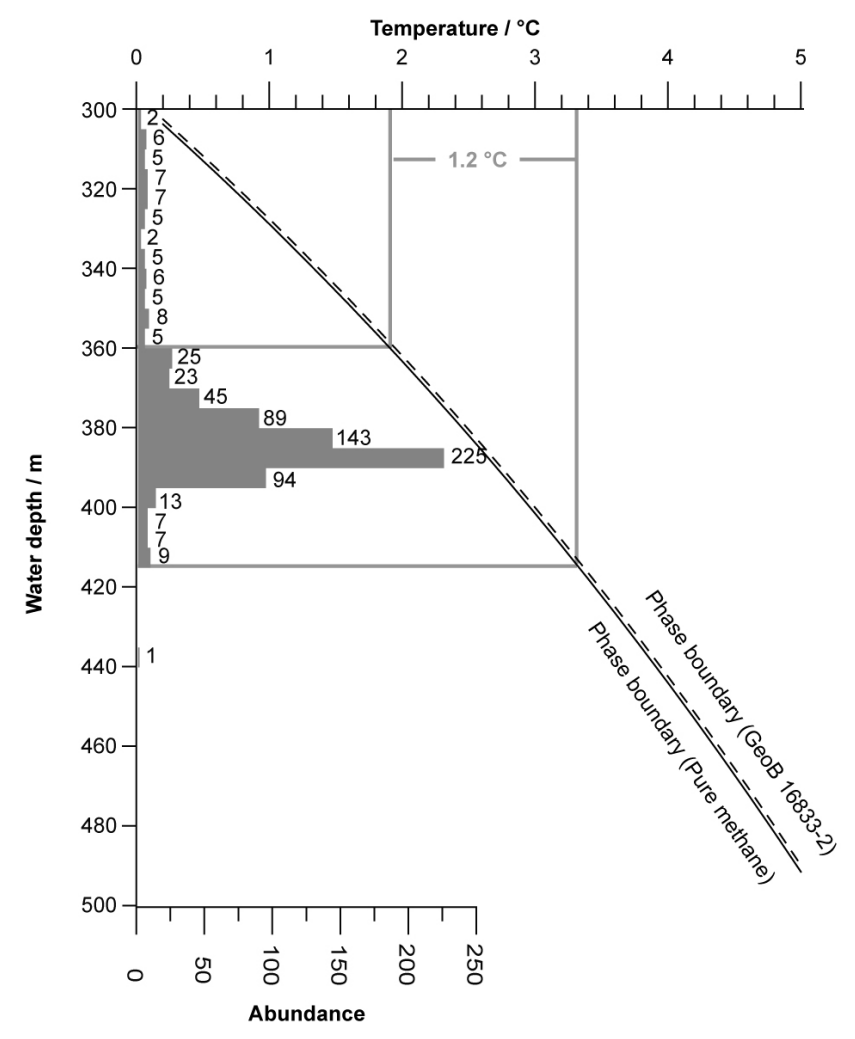

Figure 11. Composite figure showing the hydrate (structure I) phase boundary and the abundance of flares in Area 3 in $5 \mathrm{~m}$ depth intervals. Phase boundaries were calculated considering bottom-water salinity and the molecular composition of (i) gas sample GeoB 16833-2 collected with the gas bubble sampler in Area 3 (Table 2) and (ii) pure methane.

occurrence of flares in Area 3. In accordance with earlier observations, we found that the majority of gas emissions occurred along a narrow band (gray-shaded "seep area" in Fig. 8) with some additional flares located above and below that area, a pattern that was attributed to small-scale lithological heterogeneity before (Sarkar et al., 2012).

While our results do not allow for a conclusion regarding whether methane emissions in Area 3 are fed by dissociating gas hydrates, we are able to refine the depth-dependent flare distribution already proposed before Westbrook et al. (2009) with our data. The abundance of flares versus depth in Area 3 is shown in Fig. 11. Because the depth-related abundance of flares resembles a Gaussian distribution, a generic link between depth and gas emission is intuitive.

Because most flares occurred between about 360 and $415 \mathrm{~m}$ water depth, it is tempting to calculate the sediment temperature increase which would be required to induce hydrate dissociation. For this, we calculated the gas hydrate phase boundary using the composition of gas sample GeoB 16833-2 collected with the GBS (Fig. 11). The resulting increase in sediment temperature of $1.2^{\circ} \mathrm{C}$ is in agreement with both hypothesis proposed to explain the narrow zone of flare origins at the seafloor: a $1{ }^{\circ} \mathrm{C}$ temperature increase during the last 30 years (Westbrook et al., 2009) and a seasonal fluctuation of $1-2^{\circ} \mathrm{C}$ as measured with the MASOX lander (Berndt et al., 2014).

Based on the seafloor flare distribution determined in this study, we conclude that if gas hydrate dissociation is a cause of seafloor gas emissions, this process was spatially limited to one segment at the continental margin (west of Prins Karls Forland) during the time of our investigation. Furthermore, the presence of numerous additional flares at the shelf suggests that this particular region west of Prins Karls Forland is prone to hydrocarbon seepage and that gas seafloor emission unaffected by gas hydrate dissociation is common in the region.

\subsection{Quantification of gas bubble emissions}

Combining hydroacoustic data with ROV-based observations, we quantified the flux of methane as gas bubbles from the seafloor to the water column. This approach is advantageous because it is relatively simple and straight forward, providing order-of-magnitude estimations for gas bubble fluxes. Similar methodologies were recently applied in other settings characterized by gas bubble emissions (Römer et al., 2012a, b, 2014; Sahling et al., 2009).

Here, we discuss two major sources of uncertainty in our flux calculations that we regard as most important. Our estimation is a snapshot in time, taken in a few days in Aug/September 2012. This is especially important in light of the recently posed hypothesis (Berndt et al., 2014) that a temperature-induced annual build-up and break-down of hydrates would lead to an annual cycle in the gas emissions. Our results show that the gas emissions were persistent for hours (ROV observations) or even days (repeated hydroacoustic observations, Fig. 9; Table 4). In addition, gas emissions were encountered each year after their discovery in 2008 (Westbrook et al., 2009), 2009 (Fisher et al., 2011; Rajan et al., 2012), 2010 (Gentz et al., 2014), 2011 (Wright, 2012), and 2012 (Berndt et al., 2014; this study). All investigations of gas emissions in that region so far have been carried out in the summer period, and therefore it is uncertain whether the gas emissions undergo annual periodicity. In order to test the hypothesis by Berndt et al. (2014), a research campaign in spring, when bottom water temperatures are minimal and the thickness of the GHSZ should peak (and thus bubble emission may be minimal), would be useful. In this study, we state gas fluxes per year for comparative purposes (see below), although the temporal variability of gas emissions is unknown.

Our quantification approach revealed a source of uncertainty that requires a technical solution, i.e., an answer to the question of how many individual streams of bubble contribute to one flare as imaged by a ship-mounted multibeam echosounder. By use of the ROV-mounted horizontally looking sonar, we found that a single bubble stream is enough to 
cause a flare but that sometimes up to 15 bubble streams contribute to one flare (Table 3). While the bubble flux of a single bubble stream can be appropriately determined by using a ROV (visually or by capturing the bubbles), and the numbers of flares can be systematically mapped using multibeam, the uncertainty introduced in the bubble-stream-to-flare ratio is a factor of $>10$. In this study, we employed the ROV-mounted sonar for this purpose, but encountered several shortages, i.e., the difficulty in keeping the ROV stationary in strong bottomwater currents and the need for very long scanning times consuming a lot of highly valuable ROV operation time. A towed sonar system or a sonar on a bottom-mounted lander system would be a desirable technical innovation.

The bubble flux of methane in Areas 2 (5 to $68 \times 10^{6} \mathrm{~mol} \mathrm{yr}^{-1}$ ) and 3 ( 4 to $50 \times 10^{6} \mathrm{~mol} \mathrm{yr}^{-1}$ ) estimated in this study is similar to the range of fluxes $(0.23$ to $87 \times 10^{6} \mathrm{~mol} \mathrm{yr}^{-1}$ ) in other bubble emission settings (Table $6)$. Because bubble fluxes in all these settings are on the same order of magnitude, this gives us confidence that our approach used for estimating the flux in this study is reliable.

Our estimation of the bubble flux contributes to the ongoing discussion regarding the amount of gas hydrate in the upper continental slope west of Svalbard that is susceptible to temperature changes. We base the following discussion on the assumption that most of the methane is released as gas bubbles from the seafloor when hydrates within the seafloor are dissociating. We neglect the amount of methane that is consumed by oxidation within the seafloor or that is emitted dissolved in the aqueous phase, as we have no control over these processes. In order to compare flux rates determined in this study with those given in the literature for hydrate dissociation, we converted published rates into the annual methane flux per meter of margin segment $\left(\mathrm{mol} \mathrm{m}^{-1} \mathrm{yr}^{-1}\right)$. Our systematic flare mapping revealed that the gas emissioninfluenced margin segment has a length of $\sim 14 \mathrm{~km}$ (Areas 2 and 3, Figs. 5 and 8), which is short compared to those (30 and $25 \mathrm{~km}$, respectively) investigated in other related studies (Westbrook et al., 2009; Marín-Moreno et al., 2013).

Overall, the bubble flux estimated in this study is lower than the amount of methane released from dissociating hydrates reported earlier (Table 7). However, the published rates span 3 orders of magnitude, with minimum rates being consistent with our estimates. Westbrook et al. (2009) initially estimated methane release from dissociating hydrates at about $56 \times 10^{3} \mathrm{~mol} \mathrm{~m}^{-1} \mathrm{yr}^{-1}$. Based on 2-D modeling, Reagan et al. (2011) scaled this value down to $8.8 \times 10^{3} \mathrm{~mol} \mathrm{~m}^{-1} \mathrm{yr}^{-1}$, which is about the same order of magnitude as our bubble-flux estimate (0.6 to $\left.8.4 \times 10^{3} \mathrm{~mol} \mathrm{~m}^{-1} \mathrm{yr}^{-1}\right)$. These fluxes are based on an increase in bottom-water temperature of about $1{ }^{\circ} \mathrm{C}$ during the past three decades considering progressive hydrate dissociation at present. If the gas emission in Areas 2 and 3 are sourced by temperature-induced multi-year hydrate dissociation, the model by Reagan et al. (2011) appears to be most applicable.
The impact of future bottom-water warming on hydrates in sediments of the upper continental slope west of Svalbard was modeled by Marín-Moreno et al. (2013) using climate models and scenarios representing low and high greenhouse emissions (i.e., representative concentration pathways 2.6 and 8.5, respectively). In the next 100 years, the hydrate dissociation rate is forecasted to be 6.9 to $20.6 \times 10^{3} \mathrm{~mol} \mathrm{~m}^{-1} \mathrm{yr}^{-1}$, with acceleration to 13.2 to $72.3 \times 10^{3} \mathrm{~mol} \mathrm{~m}^{-1} \mathrm{yr}^{-1}$ within the next 300 years. These rates are again higher compared to those determined for present bubble emissions in this study. The predictions by Marín-Moreno et al. (2013) call for monitoring of the hydrate deposits west of Svalbard in the future.

According to Berndt et al. (2014), release of methane from the dynamic hydrate reservoir amounts to 561 to $935 \times 10^{3} \mathrm{~mol} \mathrm{~m}^{-1} \mathrm{yr}^{-1}$, which is 2 orders of magnitude higher than the bubble flux that we estimate. The discrepancy between these values warrants further investigation. A first approach could be to test whether bubble emission intensities actually vary during the year.

Because methane is a potent greenhouse gas, the fate of methane emitted from the seafloor is of relevance. Gentz et al. (2014) showed for the well-stratified water column in Area 2 during the summer that the majority of methane is diffusing from bubbles into the water column below the pycnocline and leads to relative enrichments in the concentrations of dissolved methane in the lower water body. However, as the lower water body is isolated from the upper water layer by the density difference (the pycnocline), methane dissolved in lowermost water masses does not reach the atmosphere. Therefore, most of the methane emitted from the seafloor is either oxidized or transported in the water mass and further diluted, or it reaches the sea surface, where it could escape into the atmosphere. Complete methane removal by oxidation occurs within about 50 to 100 days (Gentz et al., 2014). Therefore, the fate of methane depends on the time frame and fate of the water mass. The situation is different in autumn, when storms and low temperatures break down the water column stratification and induce vertical mixing. Although not studied so far, it might be expected that bubble-forming methane gets dissolved in the water and transported through the water-air interface into the atmosphere, contributing to the atmospheric methane inventory.

\section{Conclusions}

At the upper slope (Area 3) and outer continental shelf (Area 2), methane of microbial origin is emitted at the seafloor. Based on our data, we cannot contribute to the question of whether gas hydrate dissociation is the cause of the observed bubble emissions and, further, whether a multi-year warming trend $\left(1^{\circ} \mathrm{C}\right.$ in 30 years) or a seasonal temperature cycle is the driver of the hydrate dissociation. But our data show that if hydrate dissociation in Areas 2 and 3 occurs, it is spatially 
Table 6. Fluxes of bubble-forming methane from the seafloor to the hydrosphere in various regions.

\begin{tabular}{|c|c|c|c|}
\hline $\begin{array}{l}\text { Methane bubble flux } \\
\left(10^{6} \mathrm{~mol} \mathrm{yr}^{-1}\right)\end{array}$ & Water depth (m) & Area & Reference \\
\hline 27 (5 to 68$)$ & $240-245$ & Area 2 & This study \\
\hline $26(4$ to 50$)$ & $380-390$ & Area 3 & This study \\
\hline$\sim 19$ & $1250-1270$ & $\begin{array}{l}\text { Håkon Mosby Mud Volcano - } \\
\text { all three emission sites }\end{array}$ & Sauter et al., 2006 \\
\hline 2 to 87 & 890 & Kerch Flare, Black Sea & Römer et al., 2012a \\
\hline 21.9 & $600-700$ & $\begin{array}{l}\text { Northern summit of Hydrate } \\
\text { Ridge, offshore Oregon }\end{array}$ & Torres et al., 2002 \\
\hline 1.5 & $65-75$ & Tommeliten field, North Sea & Schneider von Deimling et al., 2011 \\
\hline $40( \pm 32)$ & $575-2870$ & $\begin{array}{l}\text { Makran continental margin } \\
(50 \mathrm{~km} \text { broad segment })\end{array}$ & Römer et al., 2012b \\
\hline 0.23 to 2.3 & 1690 & $\begin{array}{l}\text { Carbonate slab, Nile Deep Sea } \\
\text { Fan }\end{array}$ & Römer et al., 2014 \\
\hline
\end{tabular}

Table 7. Amount of methane either released as bubbles from the seafloor (this study) or susceptible to temperature-induced hydrate dissociation as revealed from modeling.

\begin{tabular}{|c|c|c|c|c|}
\hline Description & $\begin{array}{l}\text { Amount methane } \\
\left(10^{6} \mathrm{~mol} \mathrm{yr}^{-1}\right)\end{array}$ & $\begin{array}{l}\text { Margin width } \\
(\mathrm{km})\end{array}$ & $\begin{array}{l}\text { Amount methane } \\
\left(10^{3} \mathrm{~mol} \mathrm{yr}^{-1} \mathrm{~m}^{-1}\right)\end{array}$ & Reference \\
\hline Methane flux as bubbles (Area 2) & 27 (5 to 68$)$ & 4.5 & $6.0(1.1$ to 15.1$)$ & This study \\
\hline Methane flux as bubbles (Area 3) & $26(4$ to 50$)$ & 11 & $2.4(0.4$ to 4.5$)$ & This study \\
\hline $\begin{array}{l}\text { Methane flux as bubbles } \\
\text { (Area } 2 \& 3 \text { ) }\end{array}$ & 53 (9 to 118$)$ & $\sim 14$ & $3.8(0.6$ to 8.4$)$ & This study \\
\hline Progressive dissociation of hydrate & 1683 & 30 & 56.1 & Westbrook et al., 2009 \\
\hline Progressive dissociation of hydrate & 264 & 30 & 8.8 & Reagan et al., 2011 \\
\hline $\begin{array}{l}\text { Future (100 years) dissociation } \\
\text { of hydrates }\end{array}$ & 171 to 514 & 25 & 6.9 to 20.6 & Marín-Moreno et al., 2013 \\
\hline $\begin{array}{l}\text { Future ( } 300 \text { years) dissociation } \\
\text { of hydrates }\end{array}$ & 330 to 1807 & 25 & 13.2 to 72.3 & Marín-Moreno et al., 2013 \\
\hline $\begin{array}{l}\text { Annual hydrate formation and } \\
\text { dissociation }\end{array}$ & & & 561 to 935 & Berndt et al., 2014 \\
\hline
\end{tabular}

limited to a margin segment of about $14 \mathrm{~km}$ and does not occur along the $\sim 80 \mathrm{~km} 396 \mathrm{~m}$ isobath to the north. Our quantification of gas emissions in Areas 2 and 3 reveals methane fluxes on the same order of magnitude as found at bubble vents in other geological settings. If hydrate dissociation is involved, our flux estimate may help to refine models on this temperature-susceptible reservoir and will serve as a baseline if warming leads to intensified gas emissions in the future.

The gas emissions in Areas 2 and 3 are only one aspect of fluid flow offshore Svalbard, as bubble vents have been found all over the shelf and are especially prominent at the Forlandet moraine complex (Area 1), reflecting that the area west of Prins Karls Forland is prone to gas venting. We speculate that decaying permafrost may allow for methane to escape from a deeper reservoir at the Forlandet moraine complex at water depth around $90 \mathrm{~m}$.
Acknowledgements. We thank the captain and crew of $\mathrm{R} / \mathrm{V}$ Heincke cruise He-387. This work was funded through the DFG Research Centre/Excellence Cluster "The Ocean in the Earth System" MARUM - Center for Marine Environmental Sciences. M. Tomczyk was supported by SENSEnet, a Marie Curie Initial Training Network funded by the European Commission 7th Framework Programme, contract no. PITN-GA-2009-237868.

Edited by: K. Fennel 


\section{References}

Archer, D. and Buffett, B.: Time-dependent response of the global ocean clathrate reservoir to climate and anthropogenic forcing, Geochem. Geophys. Geosy., 6, Q03002, doi:10.1029/2004GC000854, 2005.

Berndt, C., Feseker, T., Treude, T., Krastel, S., Liebetrau, V., Niemann, H., Bertics, V. J., Dumke, I., Dünnbier, K., Ferré, B., Graves, C., Gross, F., Hissmann, K., Hühnerbach, V., Krause, S., Lieser, K., Schauer, J., and Steinle, L.: Temporal constraints on hydrate-controlled methane seepage off Svalbard, Science, 343, 284-287, doi:10.1126/science.1246298, 2014.

Chabert, A., Minshull, T. A., Westbrook, G. K., Berndt, C., Thatcher, K. E., and Sarkar, S.: Characterization of a stratigraphically constrained gas hydrate system along the western continental margin of Svalbard from ocean bottom seismometer data, J. Geophys. Res., 116, B12102, doi:10.1029/2011jb008211, 2011.

Damm, E., Mackensen, A., Budéus, G., Faber, E., and Hanfland, C.: Pathways of methane in seawater: Plume spreading in an Arctic shelf environment (SW-Spitsbergen), Cont. Shelf Res., 25, 14531472,2005

Eiken, O., and Hinz, K.: Contourites in the Fram Strait, Sediment. Geol., 82, 15-32, doi:10.1016/0037-0738(93)90110-Q, 1993.

Fisher, R. E., Sriskantharajah, S., Lowry, D., Lanoisellé, M., Fowler, C. M. R., James, R. H., Hermansen, O., Lund Myhre, C., Stohl, A., Greinert, J., Nisbet-Jones, P. B. R., Mienert, J., and Nisbet, E. G.: Arctic methane sources: Isotopic evidence for atmospheric inputs, Geophys. Res. Lett., 38, L21803, doi:10.1029/2011g1049319, 2011.

Gentz, T., Damm, E., Schneider von Deimling, J., Mau, S., McGinnis, D. F., and Schlüter, M.: A water column study of methane around gas flares located at the West Spitsbergen continental margin, Cont. Shelf Res., 72, 107-118, doi:10.1016/j.csr.2013.07.013, 2014.

Hustoft, S., Bünz, S., Mienert, J., and Chand, S.: Gas hydrate reservoir and active methane-venting province in sediments on $<20$ Ma young oceanic crust in the Fram Strait, offshore NW-Svalbard, Earth Planet. Sc. Lett., 284, 12-24, doi:10.1016/j.epsl.2009.03.038, 2009.

Jakobsson, M., Macnab, R., Mayer, L., Anderson, R., Edwards, M., Hatzky, J., Schenke, H.-W., and Johnson, P.: An improved bathymetric portrayal of the Arctic Ocean: Implications for ocean modeling and geological, geophysical and oceanographic analyses, Geophys. Res. Lett., 35, doi:10.1029/2008GL033520, 2008.

Knies, J., Damm, E., Gutt, J., Mann, U., and Pimnturier, L.: Nearsurface hydrocarbon anomalies in shelf sediments off Spitsbergen: Evidence for past seepages, Geoch., Geophys., Geosy., 5, doi:10.1029/2003GC000687, 2004.

Landvik, J. Y., Bondevik, S., Elverhoi, A., Fjeldskaar, W., Mangerud, J., Salvigsen, O., Siegert, M. J., Svendsen, J.-I., and Vorren, T. O.: The last glacial maximum of Svalbard and the Barents Sea area: Ice sheet extent and configuration, Quaternary Sci. Rev., 17, 43-75, 1998.

Landvik, J. Y., IngÓLfsson, Ó., Mienert, J., Lehman, S. J., Solheim, A., ElverhØI, A., and Ottesen, D. A. G.: Rethinking Late Weichselian ice-sheet dynamics in coastal NW Svalbard, Boreas, 34, 7-24, doi:10.1111/j.1502-3885.2005.tb01001.x, 2005.

Marín-Moreno, H., Minshull, T. A., Westbrook, G. K., Sinha, B., and Sarkar, S.: The response of methane hydrate beneath the seabed offshore Svalbard to ocean warming during the next three centuries, Geophys. Res. Lett., 40, 5159-5163, doi:10.1002/grl.50985, 2013.

Masoudi, R., and Tohidi, B.: Estimating the hydrate zone in the presence of salts and/or organic inhibitors using water partial pressure, J. Petrol. Sci. Eng., 46, 23-36, doi:10.1016/j.petrol.2004.10.002, 2005.

Ottesen, D. A. G., Dowdeswell, J. A., Landvik, J. Y., and Mienert, J.: Dynamics of the Late Weichselian ice sheet on Svalbard inferred from high-resolution sea-floor morphology, Boreas, 36, 286-306, doi:10.1111/j.1502-3885.2007.tb01251.x, 2007.

Pape, T., Bahr, A., Rethemeyer, J., Kessler, J. D., Sahling, H., Hinrichs, K.-U., Klapp, S. A., Reeburgh, W. S., and Bohrmann, G.: molecular and isotopic partitioning of low-molecular-weight hydrocarbons during migration and gas hydrate precipitation in deposits of a high-flux seepage site, Chem. Geol., 269, 350-363, doi:10.1016/j.chemgeo.2009.10.009, 2010.

Rachold, V., Bolshiyanov, D. Y., Grigoriev, M. N., Hubberten, H.W., Junker, R., Kunitsky, V. V., Merker, F., Overduin, P., and Schneider, W.: Nearshore arctic subsea permafrost in transition, Eos, 88, 149-150, 2007.

Rajan, A., Mienert, J., and Bünz, S.: Acoustic evidence for a gas migration and release system in Arctic glaciated continental margins offshore NW-Svalbard, Mar. Petrol. Geol., 32, 36-49, doi:10.1016/j.marpetgeo.2011.12.008, 2012.

Reagan, M. T., Moridis, G. J., Elliott, S. M., and Maltrud, M.: Contribution of oceanic gas hydrate dissociation to the formation of Arctic Ocean methane plumes, J. Geophys Res.-Oceans, 116, C09014, doi:10.1029/2011jc007189, 2011.

Römer, M., Sahling, H., Pape, T., Bahr, A., Feseker, T., Wintersteller, P., and Bohrmann, G.: Geological control and quantity of methane ebullition from a high-flux seep area in the Black Sea - the Kerch seep area, Mar. Geol., 319-322, 57-74, 2012a.

Römer, M., Sahling, H., Pape, T., Bohrmann, G., and Spiess, V.: Quantification of gas bubble emissions from submarine hydrocarbon seeps at the Makran continental margin (offshore Pakistan), J. Geophys Res.-Oceans, 117, C10015, doi:10.1029/2011JC007424, 2012b.

Römer, M., Sahling, H., Pape, T., dos Santos Ferreira, C., Wenzhöfer, F., Boetius, A., and Bohrmann, G.: Methane fluxes and carbonate deposits at a cold seep area of the Central Nile Deep Sea Fan, Eastern Mediterranean Sea, Mar. Geol., 347, 27-42, doi:10.1016/j.margeo.2013.10.011, 2014.

Sahling, H., Bohrmann, G., Artemov, Y. G., Bahr, A., Brüning, M., Klapp, S. A., Klaucke, I., Kozlova, E., Nikolovska, A., Pape, T., Reitz, A., and Wallmann, K.: Vodyanitskii mud volcano, Sorokin trough, Black Sea: Geological characterization and quantification of gas bubble streams, Mar. Petrol. Geol., 26, 1799-1811, 2009.

Sahling, H. and cruise participants: R/V Heincke cruise report HE-387. Gas emissions at the Svalbard continental margin, Longyearbyen - Bremerhaven, 20 August-16 September 2012., Berichte, MARUM - Zentrum für Marine Umweltwissenschaften, Fachbereich Geowissenschaften, Universität Bremen, No. 291, 170 pages, 2012.

Sarkar, S., Berndt, C., Minshull, T. A., Westbrook, G. K., Klaeschen, D., Masson, D. G., Chabert, A., and Thatcher, K. E.: Seismic evidence for shallow gas-escape features associated with a retreating gas hydrate zone offshore west Svalbard, J. Geophys. Res.-Sol Ea, 117, B09102, doi:10.1029/2011jb009126, 2012. 
Sauter, E. J., Muyakshin, S. I., Charlou, J.-L., Schlüter, M., Boetius, A., Jerosch, K., Damm, E., Foucher, J.-P., and Klages, M.: Methane discharge from a deep-sea submarine mud volcano into the upper water column by gas hydrate-coated methane bubbles, Earth Planet. Sc. Lett., 243, 354-365, 2006.

Schneider von Deimling, J., Rehder, G., Greinert, J., McGinnnis, D. F., Boetius, A., and Linke, P.: Quantification of seep-related methane gas emissions at Tommeliten, North Sea, Cont. Shelf Res., 31, 867-878, 2011.

Shakova, N., Semiletov, I., Salyuk, A., Yusupov, V., Kosmach, D., and Gustafsson, Ö.: Extensive methane venting to the atmosphere from sediments of the east Siberian Arctic shelf, Science, 327, 1246-1250, doi:10.1126/science.1182221, 2010.

Solheim, A., Faleide, J. I., Andersen, E. S., ElverhØI, A., Forsberg, C. F., Vanneste, K., Uenzelmann-Neben, G., and Channell, J. E. T.: Late Cenozoic seismic stratigraphy and glacial geological development of the east Greenland and Svalbard-Barents Sea continental margins, Quaternary Sci. Rev., 17, 155-184, 1998.

Torres, M. E., McManus, J., Hammond, D., Angelis, M. A. d., Heeschen, K. U., Colbert, S. L., Tryon, M. D., Brown, K. M., and Suess, E.: Fluid and chemical fluxes in and out of sediments hosting methane hydrate deposits on Hydrate Ridge, OR, I: Hydrological provinces, Earth Planet. Sc. Lett., 201, 525-540, 2002.

Vanneste, M., Guidard, S., and Mienert, J.: Bottom-simulating reflections and geothermal gradients across the western Svalbard margin, Terra Nova, 17, 510-516, doi:10.1111/j.13653121.2005.00643.x, 2005.
Vorren, T. O., Laberg, J. S., Blaume, F., Dowdeswell, J. A., Kanyon, N. H., Mienert, J., Rumohr, J., and Werner, F.: The NorwegianGreenland Sea continental margins: Morphology and late Quaternary sedimentary processes and environment, Quaternary Sci. Rev., 17, 273-302, 1998.

Westbrook, G. K., Chand, S., Rossi, G., Long, C., Bünz, S., Camerlenghi, A., Carcione, J. M., Dean, S., Foucher, J. P., Flueh, E., Gei, D., Haacke, R. R., Madrussani, G., Mienert, J., Minshull, T. A., Nouzé, H., Peacock, S., Reston, T. J., Vanneste, M., and Zillmer, M.: Estimation of gas hydrate concentration from multicomponent seismic data at sites on the continental margins of NW Svalbard and the Storegga region of Norway, Mar. Petrol. Geol., 25, 744-758, 2008.

Westbrook, G. K., Thatcher, K. E., Rohling, E. J., Piotrowski, A. M., Pälike, H., Osborne, A. H., Nisbet, E. G., Minshull, E. A., Lanoisellé, M., James, R. H., Hühnerbach, V., Green, D., Fisher, R. E., Crocker, A. J., Chabert, A., Bolton, C., BeszczynskaMöller, A., Berndt, C., and Aquilina, A.: Escape of methane gas from the seabed along the west Spitsbergen continental margin, Geophys. Res. Lett., 36, L15608, doi:10.1029/2009GL039191, 2009.

Whiticar, M. J.: A geochemial perspective of natural gas and atmospheric methane, Org. Geoch., 16, 531-547, doi:10.1016/01466380(90)90068-B, 1990.

Wright, I. C.: RRS James Clark Ross Cruise 253 (26 Jul-25 August 2011) Arctic methane hydrates, National Oceanography Centre, Southampton, Southampton, 2012. 